\title{
Nitrogen oxides emission from two beech forests subjected to different nitrogen loads
}

\author{
B. Kitzler ${ }^{1}$, S. Zechmeister-Boltenstern ${ }^{1}$, C. Holtermann ${ }^{2}$, U. Skiba ${ }^{3}$, and K. Butterbach-Bahl ${ }^{4}$ \\ ${ }^{1}$ Federal Research and Training Centre for Forests, Natural Hazards and Landscape (BFW), Seckendorff-Gudent-Weg 8 , \\ Vienna, Austria \\ ${ }^{2}$ Sellenyg. 2-4/52, Vienna, Austria \\ ${ }^{3}$ Institute of Terrestrial Ecology, Bush Estate, Penicuik, Midlothian EH26 OQB, Scotland \\ ${ }^{4}$ Institute for Meteorology and Climate Research, Atmospheric Environmental Research, Forschungszentrum Karlsruhe, \\ Kreuzeckbahnstraße 19, 82467, Garmisch-Partenkirchen, Germany
}

Received: 1 July 2005 - Published in Biogeosciences Discuss.: 9 September 2005

Revised: 2 May 2006 - Accepted: 8 May 2006 - Published: 12 July 2006

\begin{abstract}
We analysed nitrogen oxides $\left(\mathrm{N}_{2} \mathrm{O}, \mathrm{NO}\right)$ and carbon dioxide $\left(\mathrm{CO}_{2}\right)$ emissions from two beech forest soils close to Vienna, Austria, which were exposed to different nitrogen input from the atmosphere. The site Schottenwald (SW) received $20.2 \mathrm{~kg} \mathrm{~N} \mathrm{ha}^{-1} \mathrm{y}^{-1}$ and Klausenleopoldsdorf (KL) $12.6 \mathrm{~kg} \mathrm{~N} \mathrm{ha}^{-1} \mathrm{y}^{-1}$ through wet deposition. Nitric oxide emissions from soil were measured hourly with an automatic dynamic chamber system. Daily $\mathrm{N}_{2} \mathrm{O}$ measurements were carried out by an automatic gas sampling system. Measurements of nitrous oxide $\left(\mathrm{N}_{2} \mathrm{O}\right)$ and $\mathrm{CO}_{2}$ emissions were conducted over larger areas on a biweekly (SW) or monthly (KL) basis by manually operated chambers. We used an autoregression procedure (time-series analysis) for establishing time-lagged relationships between $\mathrm{N}$-oxides emissions and different climate, soil chemistry and $\mathrm{N}$-deposition data. It was found that changes in soil moisture and soil temperature significantly effected $\mathrm{CO}_{2}$ and $\mathrm{N}$-oxides emissions with a time lag of up to two weeks and could explain up to $95 \%$ of the temporal variations of gas emissions. Event emissions after rain or during freezing and thawing cycles contributed significantly (for NO 50\%) to overall N-oxides emissions. In the two-year period of analysis the annual gaseous $\mathrm{N}_{2} \mathrm{O}$ emissions at SW ranged from 0.64 to $0.79 \mathrm{~kg} \mathrm{Nha}^{-1} \mathrm{y}^{-1}$ and NO emissions were 0.24 to $0.49 \mathrm{~kg} \mathrm{Nha}^{-1}$ per vegetation period. In $\mathrm{KL}$ significantly lower annual $\mathrm{N}_{2} \mathrm{O}$ emissions ( 0.52 to $0.65 \mathrm{~kg} \mathrm{~N}_{2} \mathrm{O}-\mathrm{N} \mathrm{kg} \mathrm{ha}^{-1} \mathrm{y}^{-1}$ ) as well as considerably lower NO-emissions were observed. During a three-month measurement campaign $\mathrm{NO}$ emissions at KL were $0.02 \mathrm{~kg} \mathrm{~N}$ $\left.\mathrm{ha}^{-1}\right)$, whereas in the same time period significantly more NO was emitted in SW $\left(0.32 \mathrm{~kg} \mathrm{NO}-\mathrm{N} \mathrm{ha}^{-1}\right)$. Higher N-

Correspondence to: $\mathrm{B}$. Kitzler

(barbara.kitzler@bfw.gv.at)
\end{abstract}

oxides emissions, especially NO emissions from the high $\mathrm{N}-$ input site (SW) may indicate that atmospheric deposition has an impact on emissions of gaseous $\mathrm{N}$ from our forest soils. At $\mathrm{KL}$ there was a strong correlation between $\mathrm{N}$-deposition and $\mathrm{N}$-emission over time, which shows that low $\mathrm{N}$-input sites are especially responsive to increasing $\mathrm{N}$-inputs.

\section{Introduction}

Nitrogen emissions are driven by soil substrate, tree species, climate, short term fluctuations of water availability as high rain, freeze thaw cycles and atmospheric inputs (e.g. Dahlgren and Singer, 1994; Fitzhugh et al., 2001; Lovett et al., 2002; MacDonald et al., 2002). The effect of Ndeposition on $\mathrm{N}$-emissions has become a major issue due to the observation of a significant worldwide increase in $\mathrm{N}$ deposition rates; a further increase is predicted as a result of an increased use of fertilizers and increased energy consumption (Galloway et al., 1995; Hall and Matson, 1999). In forest ecosystems increased $\mathrm{N}$ supply results in $\mathrm{N}$ saturation which is indicated by increased N-leaching from soils, soil acidification, forest decline, nutrient imbalances and losses, and soil emissions of $\mathrm{N}$ oxide gases (Gundersen et al., 1998; van Breemen et al., 1988; Aber et al., 1998; Skiba et al., 1999). Where $\mathrm{N}$ constitutes a limiting factor, competition between roots and microbes is high and nitrate $\left(\mathrm{NO}_{3}^{-}\right)$is taken up. This is contrary to a high $\mathrm{N}$ supply which leaves ammonium $\left(\mathrm{NH}_{4}^{+}\right)$and $\mathrm{NO}_{3}^{-}$accessible for nitrifying and denitrifying bacteria. Chemodenitrification, nitrification and denitrification are the main sources of N-oxides emissions (Davidson, 1993; Venterea et al., 2003). Forest ecosystems

Published by Copernicus GmbH on behalf of the European Geosciences Union. 
Table 1. Site and soil characteristics of the investigation sites Schottenwald and Klausenleopoldsdorf.

\begin{tabular}{|c|c|c|}
\hline & SW & KL \\
\hline Location & $48^{\circ} 14^{\prime} \mathrm{N} 16^{\circ} 15^{\prime} \mathrm{E}$ & $48^{\circ} 07^{\prime} \mathrm{N} 16^{\circ} 03^{\prime} \mathrm{E}$ \\
\hline Precipitation [mm] & $465^{1)}$ & $728^{1)}$ \\
\hline Mean air temp. $\left[{ }^{\circ} \mathrm{C}\right]$ & 9 & 8 \\
\hline Vegetation & $\begin{array}{l}\text { Lathyro-Fagetum } \\
\text { Allietosum }^{2)}\end{array}$ & $\begin{array}{l}\text { Asperulo odoratae- } \\
\text { Fagetum }^{2)}\end{array}$ \\
\hline Stand age [years] & 142 & 62 \\
\hline Exposition, elevation & SE, 370 m a.s.l. & NNE, $510 \mathrm{~m}$ a.s.l. \\
\hline Tree height $[\mathrm{m}]$ & 33 & 25.1 \\
\hline $\mathrm{DBH}[\mathrm{cm}]$ & 51 & 21.8 \\
\hline Basal area $\left[\mathrm{m}^{2} \mathrm{ha}^{-1}\right]$ & 40 & 25.6 \\
\hline Soil type & \multicolumn{2}{|c|}{ dystric cambisol over sandstone } \\
\hline Water conditions & moderately well-drained & moderately fresh \\
\hline Soil texture & silty loam & loam-loamy clay \\
\hline Soil pH 0-7 cm $\left(\mathrm{CaCl}_{2}\right)$ & 4.4 & 4.6 \\
\hline $\mathrm{C}: \mathrm{N}$ & 16 & 16 \\
\hline Soil density $\left(\mathrm{g} \mathrm{cm}^{-3}\right)$ & 0.630 & 0.827 \\
\hline $\mathrm{N}_{\text {tot }}\left(\mathrm{mg} \mathrm{g}^{-1}\right)$ & 2.38 & 4.79 \\
\hline $\mathrm{C}_{\text {org }}\left(\mathrm{mg} \mathrm{g}^{-1}\right)$ & 37.70 & 74.51 \\
\hline
\end{tabular}

1) Mean precipitation of the two observation years.

2) Mayer (1974).

with $\mathrm{N}$-inputs exceeding critical loads have been found to accumulate $\mathrm{N}$ in soil (Beier et al., 2001). However, studies in N-saturated forests in Central (Zechmeister-Boltenstern et al., 2002; Butterbach-Bahl et al., 1997; Brumme and Beese, 1992) and Northern Europe (Pilegaard et al., 1999) have shown that $\mathrm{N}$-saturated forests release significantly more $\mathrm{N}_{2} \mathrm{O}$ and, especially $\mathrm{NO}$, than $\mathrm{N}$-limited temperate forests (Davidson and Kingerlee, 1997).

In the vicinity of cities or intensively managed agricultural lands, $\mathrm{N}$-input can amount up to $50 \mathrm{~kg} \mathrm{Nha}^{-1} \mathrm{y}^{-1}$ (NADP, 2002; Tietema, 1993). Since there are only a few studies that investigated the effect of different $\mathrm{N}$-deposition on forest ecosystems under similar climatic conditions (Hahn et al., 2000; Rennenberg et al., 1998; Skiba et al., 1998; Butterbach-Bahl et al., 2002a) our approach included: (1) Field measurements of $\mathrm{CO}_{2}, \mathrm{~N}_{2} \mathrm{O}$ and $\mathrm{NO}$ emissions from soils of two beech forests with different N-deposition loads. Additionally, measurements were made in high temporal and spatial resolution to (2) get better estimates of annual emission (3) study the effects of climatic factors and soil parameters on gaseous soil emissions and (4) find an appropriate statistical procedure to describe the relationships between $\mathrm{N}$ emissions and their ecological drivers.

\section{Material and methods}

\subsection{Investigation sites and soils}

The experimental site Schottenwald (SW) is situated in direct vicinity of Vienna on a SE-exposed upper slope in a 142 year old beech stand. The soil is a moderately well drained dystric cambisol over sandstone. In spring the undergrowth is dominated by a dense cover of the geophyte Allium ursinum L. changing to bare soil in summer and autumn. The second sampling site, Klausenleopoldsdorf (KL), is located about $40 \mathrm{~km}$ south-west of Vienna on a NNE-facing slope. On site there is a 62 year old beech forest growing on a dystric cambisol displaying no significant changes in ground vegetation throughout the year. For site description see Table 1.

\section{2 $\mathrm{N}_{2} \mathrm{O}$ and $\mathrm{CO}_{2}$ flux measurements}

We used the closed chamber technique in order to cover the spatial and temporal variability of $\mathrm{N}_{2} \mathrm{O}$ and $\mathrm{CO}_{2}$ soil emissions. Gas emissions were measured by manual (4/site) and automatic chambers (1/site). A manual chamber consists of an aluminium frame $(1 \times 1 \times 0.05 \mathrm{~m})$, which we inserted into the soil to a depth of $3 \mathrm{~cm}$. A single-wall rigid polyethylene light-dome (Volume: 801 ) with a compressible PTFE seal at the bottom was fixed onto the aluminium frame by means of 4 screws.

Duplicate air samples were taken from the chambers with $60 \mathrm{ml}$ polypropylene gas-tight syringes at an interval of 0,1 and $2 \mathrm{~h}$. 


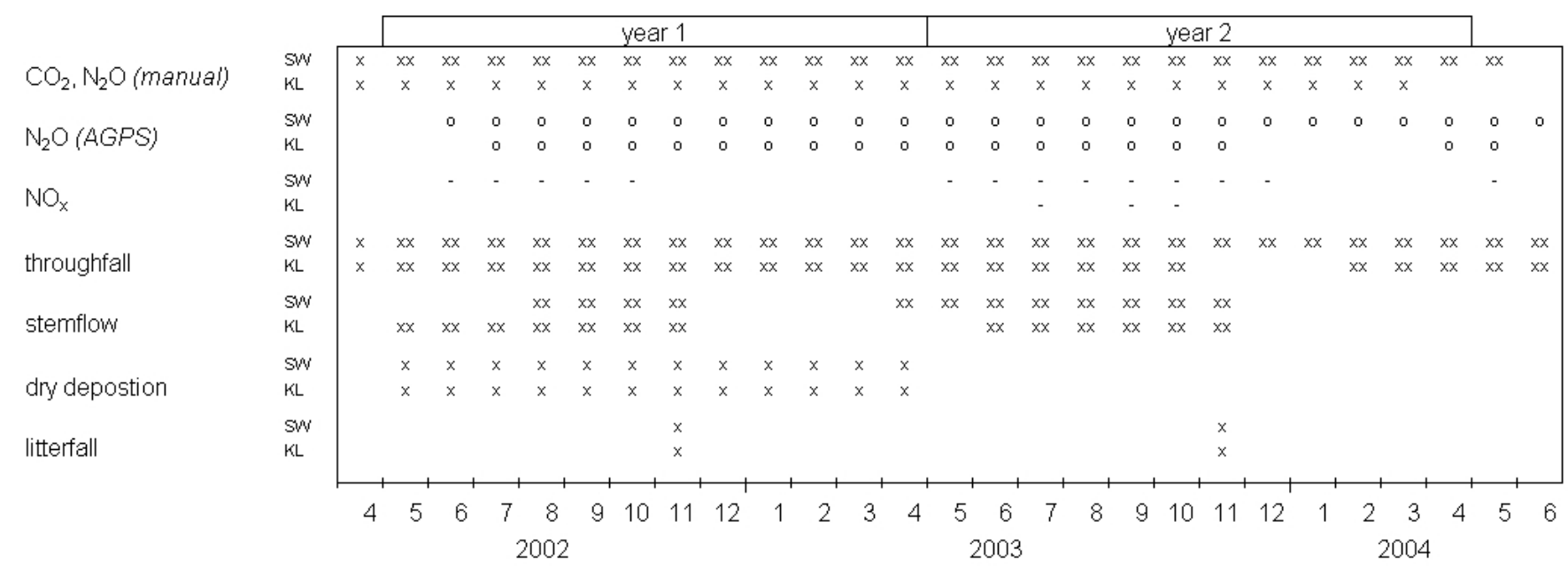

Fig. 1. Measurement frequency of $\mathrm{CO}_{2}$ and $\mathrm{N}_{2} \mathrm{O}$ emissions by manual chambers, $\mathrm{N}_{2} \mathrm{O}$ emissions by $A G P S, \mathrm{NO}_{\mathrm{x}}$ by dynamic chambers, litterfall and depositon data at Schottenwald and Klausenleopoldsdorf. $(\mathrm{x})=1 / \mathrm{month},(\mathrm{xx})=2 / \mathrm{month},(\mathrm{o})=1 / \mathrm{day},(-)=1 / \mathrm{h}$.

Linearity of emission was always tested. We never observed a flattening of the $\mathrm{N}_{2} \mathrm{O}$ increase in our chambers, which would indicate that we approached the compensation point for $\mathrm{N}_{2} \mathrm{O}$. Additional measurements every 15 minutes showed that the increase in $\mathrm{N}_{2} \mathrm{O}$ concentrations remained linear for up to 4 hours (Zechmeister-Boltenstern et al., 2002).

$30 \mathrm{ml}$ of the gas-probe were injected into evacuated and gas tight headspace vials $(20 \mathrm{ml})$, fitted with a silicon sealed rubber stopper and an aluminium cap. Samples were taken on a biweekly (SW) or monthly (KL) basis from April 2002 until May 2004 (Fig. 1).

For the measurement of short-time temporal variations (1/day) (Fig. 1) of $\mathrm{N}_{2} \mathrm{O}$ emissions an automatic gas sampling system (AGPS-patent DE 19852 859) was used (UIT GmbH, Dresden). It consists of the following main components (Fig. 2): A covering case $(0.7 \times 0.7 \mathrm{~m})$ with a rubber gasket, a slipping clutch for automatically closing and opening of the chamber and a thermostat. Within the protection case a fraction collector with 40 headspace vials $(20 \mathrm{ml})$, a control system; a vacuum pump and a memory programmable control unit with the possibility of the free determination of the sampling times; an automatic needle plug-in with a double needle; the power supply that is provided either by batteries $(2 \times 12 \mathrm{~V} / \mathrm{DC})($ at KL) or by existing power supply lines (at $\mathrm{SW})$ where a mains adapter EP-925 (230 V to $24 \mathrm{~V} / \mathrm{DC})$ was interposed.

During sampling procedure the covering case glided across to the side of the sealing plate, thus, case-tightening the chamber for $70 \mathrm{~min}$. During closure time air samples were extracted (flow rate ca. $100 \mathrm{ml} \mathrm{min}^{-1}$ ) from the chamber by a membrane pump and transported through $10 \mathrm{~m}$ Teflon tubes to the vials. Sample lines and vials were flushed for $10 \mathrm{~min}$ before samples were taken from the headspace air of the chamber. Within these $70 \mathrm{~min}$ two gas samples were taken: The first one after $10 \mathrm{~min}$, the second one after $70 \mathrm{~min}$ closure time. Automatic sampling was scheduled for 6 a.m. During winter time measurements took place at 1 p.m., thus, avoiding night/morning frost. In order to prevent the covering case from freezing on the sealing plate the thermostat was set at $1^{\circ} \mathrm{C}$ and no measurements were conducted below this temperature.

The vials with the gas samples were stored at $4{ }^{\circ} \mathrm{C}$ under water for 14 days maximum. In the laboratory gas samples were analysed for $\mathrm{N}_{2} \mathrm{O}$ by gas chromatography (HP 5890 Series II) with a ${ }^{63} \mathrm{Ni}$-electron-capture detector (ECD) connected to an automatic sample-injection system (DANI HSS 86.50, HEADSPACE-SAMPLER). Oven, injector and detector temperatures were set at $120^{\circ} \mathrm{C}, 120^{\circ} \mathrm{C}$ and $330^{\circ} \mathrm{C}$, respectively. $\mathrm{N}_{2}$ in ECD-quality served as carriergas with a flow rate of $30 \mathrm{ml} \mathrm{min}^{-1}$. The gas-chromatograph was routinely cross-calibrated with a standard of $5 \mu 11^{-1}$ $\mathrm{N}_{2} \mathrm{O}$ (Linde Gas) and dilution series were made regularly. We quantified a minimum detectable $\mathrm{N}_{2} \mathrm{O}$ flux of $0.04 \mu \mathrm{g} \mathrm{N} \mathrm{m}^{-2} \mathrm{~h}^{-1}$ and the relative error falls below $<17 \%$ with a median of $5 \% . \mathrm{CO}_{2}$ was analysed through a gas chromatograph (Hewlett-Packard 5890 II series) equipped with a thermal conductivity detector (TCD). Helium was used as carrier-gas (flow rate $10 \mathrm{ml} \mathrm{min}^{-1}$ ); the $\mathrm{CO}_{2}$ standard contained $10 \mathrm{ml}^{-1} \mathrm{CO}_{2}$ (Linde Gas). The minimum detectable $\mathrm{CO}_{2}$ flux was $0.001 \mathrm{mg} \mathrm{C} \mathrm{m}^{-2} \mathrm{~h}^{-1}$.

Emissions of $\mathrm{N}_{2} \mathrm{O}\left(\mu \mathrm{g} \mathrm{N} \mathrm{m}^{-2} \mathrm{~h}^{-1}\right)$ and $\mathrm{CO}_{2}\left(\mathrm{mg} \mathrm{Cm}^{-2}\right.$ $\mathrm{h}^{-1}$ ) were determined by the linear increase of the mixing ratio within the headspace of the closed chamber. The calculation of $\mathrm{N}_{2} \mathrm{O}$ and $\mathrm{CO}_{2}$ fluxes is described in the manual on measurement of $\mathrm{CH}_{4}$ and $\mathrm{N}_{2} \mathrm{O}$ emissions from agriculture (IAEA, 1992).

\subsection{NO flux measurements}

$\mathrm{NO}$ and $\mathrm{NO}_{\mathrm{x}}$ exchange was directly measured on site using a chemoluminiscence detector (Holtermann, 1996). The 


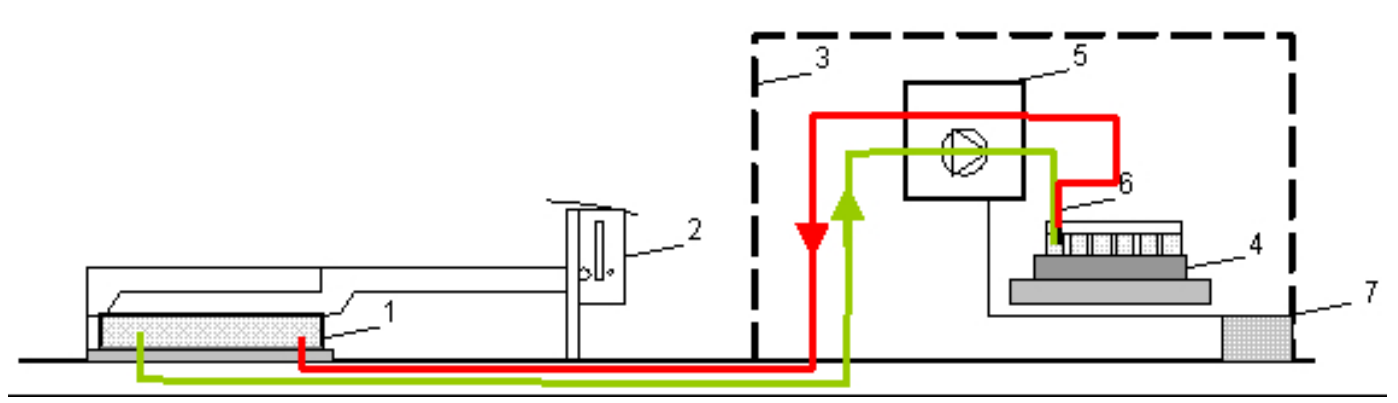

Fig. 2. Schematic of the AGPS with the main components 1) covering case; 2) slipping clutch and a thermostat; 3) protection case; 4) fraction collector; 5) control system, vacuum pump and memory programmable control unit; 6) double needle and 7) power supply.

detection limit of the $\mathrm{NO}_{\mathrm{x}}$-analyzer (HORIBA APNA-360) was $1 \mathrm{ppbv}$ NO. The detection limit of the dynamic chamber system is $0.6 \mu \mathrm{g} \mathrm{NO} \mathrm{m}^{-2} \mathrm{~h}^{-1}$. The reading for $\mathrm{NO}_{\mathrm{x}}$ of the HORIBA analyzer refers to $\mathrm{NO}, \mathrm{NO}_{2}$ and other nitrogen compounds (PAN, $\mathrm{NH}_{3}, \mathrm{HONO}, \mathrm{HNO}_{3}$, aerosol ammonium, nitrate and nitrite). We therefore use the terms NO and $\left(\mathrm{NO}_{\mathrm{x}}-\mathrm{NO}\right)$ further on. The calculated error was high for fluxes near the detection limit $(\sim 130 \%)$, whereas it was low for high NO fluxes $(\sim 3 \%)$. A median error was calculated to be $\sim 15 \%$ and $\sim 35 \%$ for $\mathrm{NO}$ and $\left(\mathrm{NO}_{\mathrm{x}}-\mathrm{NO}\right)$, respectively. Air samples were taken from six stainless steel chambers (Area: $0.03 \mathrm{~m}^{2}$; Vol: 3.271 ; flow rate: $11 \mathrm{~min}^{-1}$ ) connected to the $\mathrm{NO}_{\mathrm{x}}$-analyzer via PTFE tubing (inner diameter: $4 \mathrm{~mm}$; length: $10 \mathrm{~m}$ ). The closing (Plexiglas lid) of the dynamic chambers is initiated by a motor. One of the six dynamic chambers was used as a reference chamber by sealing the opening to the soil through a Plexiglas pane. The chambers were closed for $5 \mathrm{~min}$ within which steady state was reached. Since there was no ozone analyzer available in 2002, the chamber inlets were supplied with clean air. For this ambient air was passed through a filter cylinder filled with Purafil and activated charcoal (length: $465 \mathrm{~mm}$; diameter: $85 \mathrm{~mm}$ ). Calibration was carried out through span gas (UBA certified) of a NO concentration of $153 \pm 2 \% \mathrm{ppb}$. Zero air preparation consisted of a bottle of compressed synthetic air $\left(\mathrm{Cn} \mathrm{Hm}<0,1 \mathrm{vpm}\right.$ and $\left.\mathrm{NO}_{\mathrm{x}}<0,1 \mathrm{vpm}\right)$. Considering the basically bi-directional nature of $\mathrm{NO}$ exchange, the operation of dynamic chambers under "zero-gas" conditions (NO free air) can lead to an overestimation of NO fluxes due to exposing the enclosed soil to low NO concentrations (Ludwig et al. 2001). As the NO fluxes measured from our chambers are very low and NO concentrations are under calculated compensation points of $50 \mathrm{ppbv}(\mathrm{SW})$ and $24 \mathrm{ppbv}$ (KL) (at $15^{\circ} \mathrm{C}$ ) determined in a laboratory experiment the error using "zero-gas" was neglible in our case.

In 2002, the flux rate of NO was calculated based on the equation described in Schindlbacher et al. (2004). In year 2003, both, $\mathrm{NO},\left(\mathrm{NO}_{\mathrm{x}}-\mathrm{NO}\right)$ concentrations and $\mathrm{O}_{3}$ concentrations (HORIBA APOA-360) were measured in the chamber atmosphere without using a filter. Nitric oxide and $\left(\mathrm{NO}_{\mathrm{x}}-\right.$ NO) fluxes were calculated as described in Butterbach-Bahl et al. (1997), thus, taking the chemical reaction occurring between $\mathrm{O}_{3}$ and $\mathrm{NO}$ in the chambers and in the tubing into account (Eq. 1).

$$
\begin{aligned}
& F=\frac{Q \cdot\left(m \mathrm{NO}_{m c}-m \mathrm{NO}_{r c}\right) \cdot \mathrm{M}_{\mathrm{N}} \cdot 60 \cdot 10^{6}}{V_{m} \cdot A \cdot 10^{9}} \\
& m \mathrm{NO}_{m c}=k_{3} \cdot m \mathrm{NO}_{t} \cdot m \mathrm{O}_{3 t} \cdot t_{m c}+m \mathrm{NO}_{t} \\
& m \mathrm{NO}_{t}=\frac{\left(m \mathrm{O}_{3}-m \mathrm{NO}\right) m \mathrm{NO}}{m \mathrm{O}_{3} \cdot 10^{\left(-k 3 \cdot\left(m \mathrm{O}_{3}-m \mathrm{NO}\right) \cdot t_{t}\right)}-m \mathrm{NO}} \\
& m \mathrm{O}_{3 t}=\frac{\left(m \mathrm{NO}-m \mathrm{O}_{3}\right) m \mathrm{O}_{3}}{m \mathrm{NO} \cdot 10^{\left(-k 3 \cdot\left(m \mathrm{NO}-m \mathrm{O}_{3}\right) \cdot t_{t}\right)}-m \mathrm{O}_{3}}
\end{aligned}
$$

Where $F$ is the flux rate $\left[\mu \mathrm{g} \mathrm{N} \mathrm{m}^{-2} \mathrm{~h}^{-1}\right], Q$ is the mass flow rate of air through the chamber $\left(\sim 0.001 \mathrm{~m}^{3} \mathrm{~min}^{-1}\right)$, $m \mathrm{NO}_{m c}=$ corrected mixing ratio for $\mathrm{NO}$ in the measuring chamber [ppbv], $m \mathrm{NO}_{r c}=$ corrected mixing ratio of $\mathrm{NO}$ in the reference chamber, $\mathrm{M}_{\mathrm{N}}$ is the atomic weight of $\mathrm{N}$ $\left(=14.0067 \mathrm{~g} \mathrm{~mol}^{-1}\right), V_{m}$ is the standard gaseous molar volume $\left(24.055 \cdot 10^{-3} \mathrm{~m}^{3} \mathrm{~mol}^{-1}\right)$, and $A$ is the soil surface area of the chamber $\left(0.0314 \mathrm{~m}^{2}\right), k_{3}=1,810^{-12} \mathrm{e}^{(1370 / T)}$ $\left[\mathrm{cm}^{3}\right.$ molecule $\mathrm{s}^{-1}$ ] or $4,810^{-2} \mathrm{e}^{(1370 / T)}\left[\mathrm{ppbv}^{-1} \mathrm{~min}^{-1}\right]$, $m \mathrm{NO}_{t}=$ corrected mixing ratio for $\mathrm{NO}$ at the beginning of the tubing system [ppbv], $m \mathrm{O}_{3 t}=$ corrected mixing ratio for $\mathrm{O}_{3}$ at the beginning of the tubing system [ppbv], $t_{m c}$ residence time of sample air in the measuring chamber $[\mathrm{s}], m \mathrm{NO}=$ mixing ratio detected by the NO-analyzer [ppbv], $m \mathrm{O}_{3}=$ mixing ratio of $\mathrm{O}_{3}$ detected by the $\mathrm{O}_{3}$-analyzer [ppbv], $T=$ temperature $[\mathrm{K}], t_{t}=$ residence time of sample air in the tubing [s].

$\left(\mathrm{NO}_{\mathrm{x}}-\mathrm{NO}\right)$ was calculated in analogy to $\mathrm{NO}$ flux rates (Butterbach-Bahl et al., 1997) using the $\left(\mathrm{NO}_{\mathrm{x}}-\mathrm{NO}\right)$-converter efficiency that was determined at the UBA, Vienna.

In our calculations we have not considered losses of $\mathrm{NO}$, $\left(\mathrm{NO}_{\mathrm{x}}-\mathrm{NO}\right)$ or $\mathrm{O}_{3}$ to the chamber walls, since a previous study by Ludwig (1994) showed that e.g. deposition of $\mathrm{NO}_{\mathrm{x}}$ to the chamber walls may in maximum contribute $<20 \%$ to the total deposition flux even if the $\mathrm{NO}_{\mathrm{x}}$ mixing ratio within the chamber was $>15 \mathrm{ppbv}$. In view of the low concentrations and the spatial heterogeneity of $\mathrm{NO}_{\mathrm{x}}$ fluxes the uncertainty coming from disregarding wall effects was therefore 
assumed to be of minor importance. An error analyses revealed that $\mathrm{O}_{3}$ loss to chamber walls is not a source of concern. If $\mathrm{O}_{3}$ would be lost by as much as $30 \%$, as reported by Ludwig (1994) for full Perspex chambers, the change of NO flux is less than $0.2 \mu \mathrm{g} \mathrm{N} \mathrm{m}^{-2} \mathrm{~h}^{-1}$ which is smaller than the detection limit.

\subsection{Soil samples}

Around the chambers square plots of $4 \times 4 \mathrm{~m}^{2}$ were marked. Every 2 months samples of the organic layer (frame $30 \times 30 \mathrm{~cm}$ ) and mineral soil (metal cylinder with $5 \mathrm{~cm}$ height, $7 \mathrm{~cm}$ diameter) were taken from the corners of each plot, moving clockwise in order to avoid re-sampling at the same spot. No soil samples were taken during times of snow cover. Four soil samples of each plot were pooled and sieved through a 2-mm sieve. Litter samples were pooled and ground. Soil and litter samples were analysed for extractable $\mathrm{NH}_{4}^{+}-\mathrm{N}$ and $\mathrm{NO}_{3}^{-}-\mathrm{N}$ concentrations, soil moisture and $\mathrm{pH}$. Ammonium and $\mathrm{NO}_{3}^{-}$were extracted from soil with $0.1 \mathrm{M} \mathrm{KCl}$. Ammonium was determined by a modified indophenol reaction (Kandeler, 1995). Nitrate was measured as $\mathrm{NO}_{2}^{-}-\mathrm{N}$ after reduction by copper sheathed zinc granulates. Values are reported in $\mu \mathrm{g} \mathrm{N} \mathrm{g}^{-1}$ soil dry weight (dw). Soil moisture was determined gravimetrically and the $\mathrm{pH}$ was measured in soil suspensions in $0.01 \mathrm{M} \mathrm{CaCl}_{2}$ solution using a glass electrode.

\subsection{Meteorological data}

Air temperature $\left({ }^{\circ} \mathrm{C}\right)$ and relative humidity $(\%)$ were measured with a combined temperature moisture sensor at $2 \mathrm{~m}$ above ground. Daily precipitation was taken from the nearest meteorological stations in Mariabrunn ( $2.7 \mathrm{~km}$ from SW) and in Alland ( $7 \mathrm{~km}$ from KL). Soil temperature was measured by thermocouples; and soil water content by a water content reflectometer (CS615) at a soil depth of $5 \mathrm{~cm}, 15 \mathrm{~cm}$ and $30 \mathrm{~cm}$ in $S W$ and $15 \mathrm{~cm}, 30 \mathrm{~cm}$ and $60 \mathrm{~cm}$ in KL. Data were stored at an interval of $0.5 \mathrm{~h}$ in the data logger (Delta-T Logger).

\subsection{Deposition measurements}

Wet deposition was collected biweekly using 10 and 15 throughfall collectors, and 2 and 3 stemflow collectors at SW and KL, respectively. Litterfall was collected in three collectors. Wet deposition and litterfall was analysed for $\mathrm{NH}_{4}^{+}-\mathrm{N}$ and $\mathrm{NO}_{3}^{-}-\mathrm{N}$. Dry deposition as one component of the $\mathrm{N}$ budget comprises $\mathrm{NH}_{3}$ and $\mathrm{NO}_{2}$, but also dry deposition of $\mathrm{NO}$ (if soil compensation mixing ratio is exceeded), $\mathrm{HONO}, \mathrm{HNO}_{3}$, PAN, aerosol ammonium, nitrate and nitrite. In this study concentrations of nitrogen dioxide $\left(\mathrm{NO}_{2}\right)$ and ammonia $\left(\mathrm{NH}_{3}\right)$ was measured by three passive diffusion tubes and three CEH ALPHA samplers (Tang, 2001) and were analysed by CEH Edinburgh. Passive diffusion samplers are widely used to monitor atmospheric concentrations of trace gases such as $\mathrm{NH}_{3}$ and $\mathrm{NO}_{2}$ (Krupa and Legge, 2000; Brown, 2000). The ammonia ALPHA sampler method (used by CEH, Edinburgh) was rigorously tested against a reference active diffusion denuder method (Sutton et al., 2001). A modification of the GRADKO diffusion tube, which is widely used in the UK was used for monitoring $\mathrm{NO}_{2}$ (Stevenson et al., 2001). This diffusion tube was modified by adding a turbulence damping membrane across the inlet and validated by Bush et al. (2001). The samplers were placed at a height of $1.5 \mathrm{~m}$ in the canopy at the forest sites and were changed monthly. In order to estimate the rates of dry deposition, deposition velocities of $1.5 \mathrm{~mm} \mathrm{~s}^{-1}$ for $\mathrm{NO}_{2}$ and $3 \mathrm{~mm}$ $\mathrm{s}^{-1}$ for $\mathrm{NH}_{3}$ (Duyzer, pers. comm.) were assumed. Concentrations of $\mathrm{NO}_{2}$ and $\mathrm{NH}_{3}$ were measured in the first investigation year (May 2002-April 2003), whereas wet deposition was measured in the first and the second (May 2003- April 2004) investigation year (Fig. 1).

\subsection{Statistical analysis}

Differences in soil emission, soil chemistry data and Ndeposition data between the sites and between the investigation years were determined using the t-test or the nonparametric Wilcoxon-test. Prior to analysis the data were checked for normal distribution and for homogeneity of variances (ttest). When normal distribution could not be achieved by log-transformation, the Wilcoxon-test was carried out. The relationships between daily, biweekly or monthly fluxes and soil, meteorological or deposition data were investigated using Pearson Correlation or Spearman rank correlation.

Soil emissions, soil, and meteorological data were serially correlated over time. We therefore used an autoregression procedure that provides regression models for time series data when the errors are autocorrelated or heteroscedastic. Data are said to be heteroscedastic (non-constant) if the variance of errors is not steady. As one of the key assumptions of the simple linear regression model is that the errors have the same variance throughout a sample the regression model has to correct for heteroscedasticity. We therefore used the generalized autoregressive conditional heteroscedasticity $(\mathrm{GARCH})$ model to correct for heteroscedasticity. The GARCH $(p, q)$ process assumes that the errors, although uncorrelated, are not independent and it models the timevarying conditional error variance as a function of the past realizations of the series (SAS/ETS, 1993). Models that take the changing variance into account can explore data more efficiently. The basic autoregressive conditional heteroscedasticity $\operatorname{ARCH}(q)$ model is the same as the $\operatorname{GARCH}(0, q)$ model, where $(p)$ references about the number of autoregressive lags and $(q)$ references about the number of moving average lags. The stepwise autoregressive error model was used for correcting autocorrelation. First, this method fits a high-order model with many autoregressive lags and then removes autoregressive parameters sequentially until 
Table 2. Wet and dry deposition and litter-fall $\left[\mathrm{kg} \mathrm{Nha}^{-1} \mathrm{y}^{-1}\right]$, precipitation $[\mathrm{mm}]$, soil nitrogen $\left[\mu \mathrm{g} \mathrm{Ng}^{-1} \mathrm{dw}\right]$ and $\left.\mathrm{pH}(\mathrm{CaCl})_{2}\right)$ in year 1 (May 2002-April 2003) and year 2 (May 2003-April 2004) at the two investigation sites Schottenwald and Klausenleopoldsdorf.

\begin{tabular}{|c|c|c|c|c|c|c|c|c|c|c|c|c|}
\hline & & \multicolumn{6}{|c|}{ SW } & \multicolumn{5}{|c|}{ KL } \\
\hline & & \multicolumn{3}{|c|}{ year 1} & \multicolumn{3}{|c|}{ year 2} & \multicolumn{2}{|c|}{ year 1} & & \multicolumn{2}{|r|}{ year 2} \\
\hline \multicolumn{13}{|c|}{$\mathrm{N}$-input by wet deposition $\left[\mathrm{kg} \mathrm{N} \mathrm{ha}^{-1} \mathrm{y}^{-1}\right]$} \\
\hline \multirow[t]{2}{*}{ throughfall } & $\mathrm{NH}_{4}^{+}-\mathrm{N}$ & 8.6 & & & 4.8 & & & 5.5 & & & 2.5 & \\
\hline & $\mathrm{NO}_{3}^{-}-\mathrm{N}$ & 7.7 & & & 9.9 & & & 6.0 & & & 2.5 & \\
\hline \multirow[t]{2}{*}{ stemflow } & $\mathrm{NH}_{4}^{+}-\mathrm{N}$ & $2.7^{1)}$ & & & 2.6 & & & 0.6 & & & 0.4 & \\
\hline & $\mathrm{NO}_{3}^{-}-\mathrm{N}$ & $1.2^{1)}$ & & & 2.1 & & & 0.5 & & & 0.3 & \\
\hline Sum of wet deposition & & 20.2 & & & 19.4 & & & 12.6 & & & 5.7 & \\
\hline \multicolumn{13}{|c|}{$\mathrm{N}$-input by dry deposition $\left[\mathrm{kg} \mathrm{Nha}^{-1} \mathrm{y}^{-1}\right]$} \\
\hline & $\mathrm{NH}_{3}-\mathrm{N}$ & 1.08 & & & n.m. & & & 0.23 & & & n.m. & \\
\hline & $\mathrm{NO}_{2}-\mathrm{N}$ & 1.30 & & & n.m. & & & 0.62 & & & n.m. & \\
\hline Sum of dry deposition & & 2.38 & & & n.m. & & & 0.85 & & & n.m. & \\
\hline Precipitation $[\mathrm{mm}]$ & & 530 & & & 400 & & & 765 & & & 690 & \\
\hline Litter-fall [kg dw ha-1 $\left.\mathrm{y}^{-1}\right]$ & & 4030 & $(177)$ & & 5963 & $(920)$ & & 6840 & & & n.m. & \\
\hline $\mathrm{N}$ - litterfall $\left[\mathrm{kg} \mathrm{N} \mathrm{ha}^{-1} \mathrm{y}^{-1}\right]$ & & 52.8 & $(3.7)$ & & 74.5 & $(10.6)$ & & 59.2 & & & n.m. & \\
\hline \multirow[t]{2}{*}{ Organic layer $\left[\mu \mathrm{g} \mathrm{Ng}^{-1} \mathrm{dw}\right]$} & $\mathrm{NH}_{4}^{+}-\mathrm{N}$ & 97.6 & $(9.4)$ & $* *$ & 55.0 & $(5.6)$ & $* *$ & 50.0 & $(4.3)$ & & 25.5 & $(1.5)$ \\
\hline & $\mathrm{NO}_{3}^{-}-\mathrm{N}$ & 19.5 & $(1.8)$ & $* *$ & 27.5 & $(2.8)$ & $*$ & 11.4 & $(1.2)$ & & 18.0 & $(2.3)$ \\
\hline $\mathrm{pH}\left(\mathrm{CaCl}_{2}\right)$ & & 5.7 & $(0.1)$ & $*$ & 5.7 & $(0.1)$ & $*$ & 5.4 & $(0.1)$ & & 5.2 & $(0.1)$ \\
\hline \multirow[t]{2}{*}{ Mineral soil $\left[\mu \mathrm{g} \mathrm{N} \mathrm{g}^{-1} \mathrm{dw}\right]$} & $\mathrm{NH}_{4}^{+}-\mathrm{N}$ & 9.4 & $(1.4)$ & & 4.0 & $(0.4)$ & & 11.5 & $(1)$ & $*$ & 5.7 & $(0.5)$ \\
\hline & $\mathrm{NO}_{3}^{-}-\mathrm{N}$ & 1.5 & $(0.3)$ & $* * *$ & 1.7 & $(0.2)$ & $*$ & 0.4 & $(0.1)$ & & 0.9 & $(0.1)$ \\
\hline $\mathrm{pH}\left(\mathrm{CaCl}_{2}\right)$ & & 4.4 & $(0.1)$ & & 4.3 & $(0.04)$ & & 4.6 & $(0.1)$ & & 4.6 & $(0.04)$ \\
\hline
\end{tabular}

Note: Deposition data and precipitation are sums. Soil data are means with standard error in parenthesis.

1) Starting from August 2002. Asterisks indicate significant differences between the sites for the individual years $(* p<0.05$, $* * p<0.01$, *** $p<0.001)$. n.m. $=$ not measured.

all remaining autoregressive parameters display significant t-tests. With this model the most significant results can be detected. The basic equation for the autoregression model used is as follows (Eq. 2):

$y_{t}=\beta_{0}+\beta_{1} x_{1 t}+\beta_{2} x_{2 t}+\ldots \beta_{n} x_{n t}+v_{t}$

$v_{t}=\varepsilon_{t}-\varphi_{1} v_{t-1}-\varphi_{2} v_{t-2}-\ldots-\varphi_{m} v_{t-m}$

$\varepsilon_{t}=\sqrt{h_{t}} e_{t}$

$h_{t}=\omega+\sum_{i=1}^{q} \alpha_{i} \varepsilon_{t-i}^{2}+\sum_{j=1}^{p} \gamma_{j} h_{t-j}$

$e_{t} \sim \operatorname{IN}(0,1)$

where $y_{t}$ is the dependent variable for time $\mathrm{t}, \beta_{0}$ is the intercept; $\beta_{1}, \beta_{2}, \ldots \beta_{n}$ are the regression coefficients of the independent variables $\left(x_{i t}, i=1 \ldots n\right)$ where $x_{1 t}$ is soil moisture in $15 \mathrm{~cm}(\mathrm{SW})$ and $30 \mathrm{~cm}(\mathrm{KL})$ soil depth, $x_{2 t}$ is soil temperature in $3 \mathrm{~cm}$ (for $\mathrm{N}_{2} \mathrm{O}$ ), $5 \mathrm{~cm}$ (for $\mathrm{NO}$ ) ( $\mathrm{SW}$ ) and $5 \mathrm{~cm}$ (KL) soil depth and $x_{3 t}$ is the $\mathrm{CO}_{2}$ emission rate. $v_{t}$ is the error term that is generated by the $j$ th order autoregressive process; $\varphi_{m}$ are the autoregressive error model parameters $\left(\mathrm{AR}_{m}\right)$. The order of the process $(m)$ defines the number of past observations on which the current observation depends; $\varepsilon_{t}$ is the unconditional variance and $h_{t}$ is the $\operatorname{GARCH}(p, q)$ conditional variance; $e_{t}$ is assumed to have a standard normal distribution; the parameters $\left(\omega\right.$ and $\left.\alpha_{1}\right)$ are $\mathrm{ARCH}(q)$ model estimates and $\left(\gamma_{1}\right)$ are GARCH $(p)$ model estimates. Statistical analysis was either completed with SAS Enterpriseguide Version 2 or SAS Version 8. All differences reported were significant at $p<0.05$ unless otherwise stated.

\section{Results}

\subsection{Meteorological data}

The two years were characterized by extreme weather conditions. In summer/autumn 2002 disastrous flooding occurred all over Europe because of persistent rainfall, followed by an extensive drought period in summer 2003. Consequently, the differences between the two seasons were pronounced, particularly in terms of soil moisture content. During both years significantly $(p<0.001)$ lower mean soil moisture was recorded in SW (28\% and $19 \%)$ in comparison to $\mathrm{KL}(42 \%$ and $37 \%$ ). Mean annual air temperature was 8.0 and $8.2^{\circ} \mathrm{C}$ at SW and KL, respectively. In the second year higher mean annual air temperatures were recorded $\left(8.6\right.$ and $\left.8.8^{\circ} \mathrm{C}\right)$. 


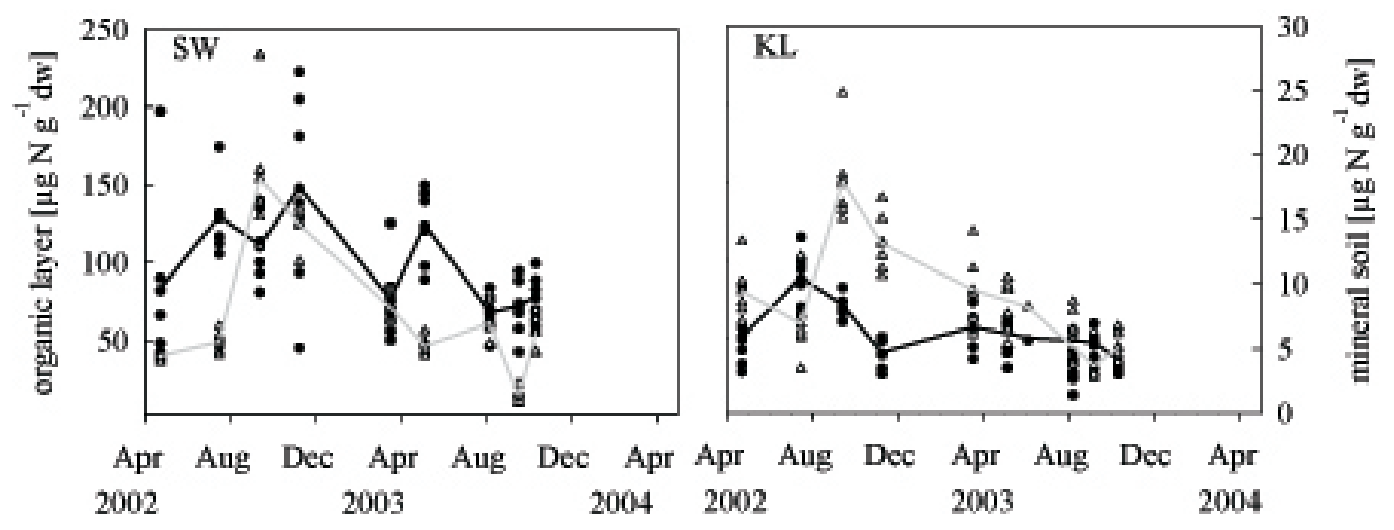

Fig. 3. Extractable soil nitrogen $\left(\mathrm{NH}_{4}^{+}-\mathrm{N}\right.$ and $\left.\mathrm{NO}_{3}^{-}-\mathrm{N}\right)$ in the litter layer (circles) and in the mineral soil $(0-5 \mathrm{~cm})($ triangles), at $\mathrm{Schottenwald}$ and at Klausenleopoldsdorf. Pooled samples $(n=4)$ were taken from around the individual chambers.

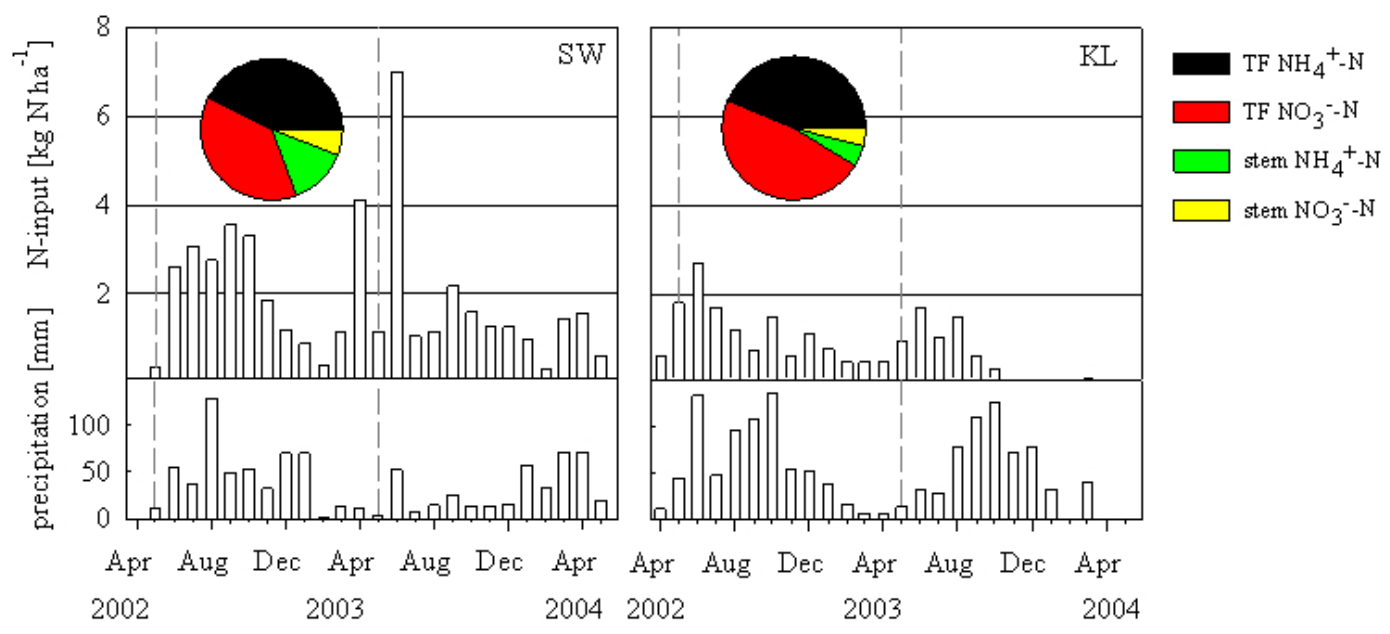

Fig. 4. Bar chart: Monthly N-input $\left(\mathrm{kg} \mathrm{N} \mathrm{ha}^{-1}\right)$ and precipitation [mm] at Schottenwald and Klausenleopoldsdorf for the years $2002-2004$. Pie charts: Portion of throughfall $\left(\mathrm{TF} \mathrm{NH}_{4}^{+}-\mathrm{N}, \mathrm{TF} \mathrm{NO}_{3}^{-}-\mathrm{N}\right)$, stem-flow $\left(\right.$ stem $\mathrm{NH}_{4}^{+}-\mathrm{N}$ and stem $\left.\mathrm{NO}_{3}^{-}-\mathrm{N}\right)$ on annual $\mathrm{N}-\mathrm{input}\left(\mathrm{kg} \mathrm{N}^{-1}\right)$ in the first investigation year (May 2002-April 2003).

\subsection{Soil nitrogen}

At both sites $\mathrm{NH}_{4}^{+}-\mathrm{N}$ concentrations in mineral soil reached highest levels with concentrations of up to $17.3 \mu \mathrm{g} \mathrm{NH}_{4}^{+}$$\mathrm{N} \mathrm{g}^{-1} \mathrm{dw}$ in $\mathrm{SW}$ and $17.9 \mu \mathrm{g} \mathrm{NH}_{4}^{+}-\mathrm{N} \mathrm{g}^{-1} \mathrm{dw}$ in $\mathrm{KL}$ in September 2002. In the first year mean $\mathrm{NH}_{4}^{+}-\mathrm{N}$ concentrations were considerably higher compared to the quantified concentrations in the second year (Table 2), whereas $\mathrm{NO}_{3}^{-}$$\mathrm{N}$ concentrations were higher in the second year. The soil in $\mathrm{SW}$ displayed highest $\mathrm{NO}_{3}^{-}-\mathrm{N}$ concentrations in summer (max: $3.4 \mu \mathrm{g} \mathrm{NO}_{3}^{-}-\mathrm{N} \mathrm{g}^{-1} \mathrm{dw}$ ) when Allium leaves had decayed completely and in autumn after litterfall (max: $2.3 \mu \mathrm{g}$ $\mathrm{NO}_{3}^{-}-\mathrm{N} \mathrm{g}^{-1} \mathrm{dw}$ ). The soil in $\mathrm{KL}$ showed highest $\mathrm{NO}_{3}^{-}-\mathrm{N}$ concentrations from August to October 2003 (up to $1.3 \mu \mathrm{g}$ $\left.\mathrm{NO}_{3}^{-}-\mathrm{N} \mathrm{g}^{-1} \mathrm{dw}\right)$.

Total extractable soil $\mathrm{N}\left(\mathrm{NO}_{3}^{-}-\mathrm{N}\right.$ and $\left.\mathrm{NH}_{4}^{+}-\mathrm{N}\right)$ concentrations were found to be significantly $(\mathrm{p}<0.001)$ higher at both sites in the first year of investigation. Concentrations of available $\mathrm{NO}_{3}^{-}-\mathrm{N}$ and $\mathrm{NH}_{4}^{+}-\mathrm{N}$ in the organic layer were about twice as large in soil samples from $\mathrm{SW}$ in comparison to $\mathrm{KL}$ but similar in terms of mineral soil (Fig. 3).

\subsection{Nitrogen input}

Nitrogen input by wet $\left(\mathrm{NO}_{3}^{-}-\mathrm{N}\right.$ and $\left.\mathrm{NH}_{4}^{+}-\mathrm{N}\right)$ and dry deposition $\left(\mathrm{NH}_{3}-\mathrm{N}\right.$ and $\left.\mathrm{NO}_{2}-\mathrm{N}\right)$, litter decomposition and mineralized $\mathrm{N}$ are demonstrated in Table 2 and Fig. 4. Nitrogen input through litterfall to the forest floor amounted to $53-75 \mathrm{~kg} \mathrm{~N}$ per ha ${ }^{-1} \mathrm{y}^{-1}$ at SW, whereas in KL N-input through litterfall amounted to $59 \mathrm{~kg} \mathrm{~N}$ per ha $\mathrm{ha}^{-1} \mathrm{y}^{-1}$.

Differences between the sites regarding the stem-flow of $\mathrm{N}$ were significant $(\mathrm{p}<0.05)$ in both years; differences in $\mathrm{N}$ from throughfall were significant in the second year. Concentration of $\mathrm{NH}_{3}, \mathrm{NO}_{2}$ was measured in the first year and amounted to 14.3 and $3.0 \mu \mathrm{g} \mathrm{NH}_{3} \mathrm{~m}^{-3}$ and 115.4 and 


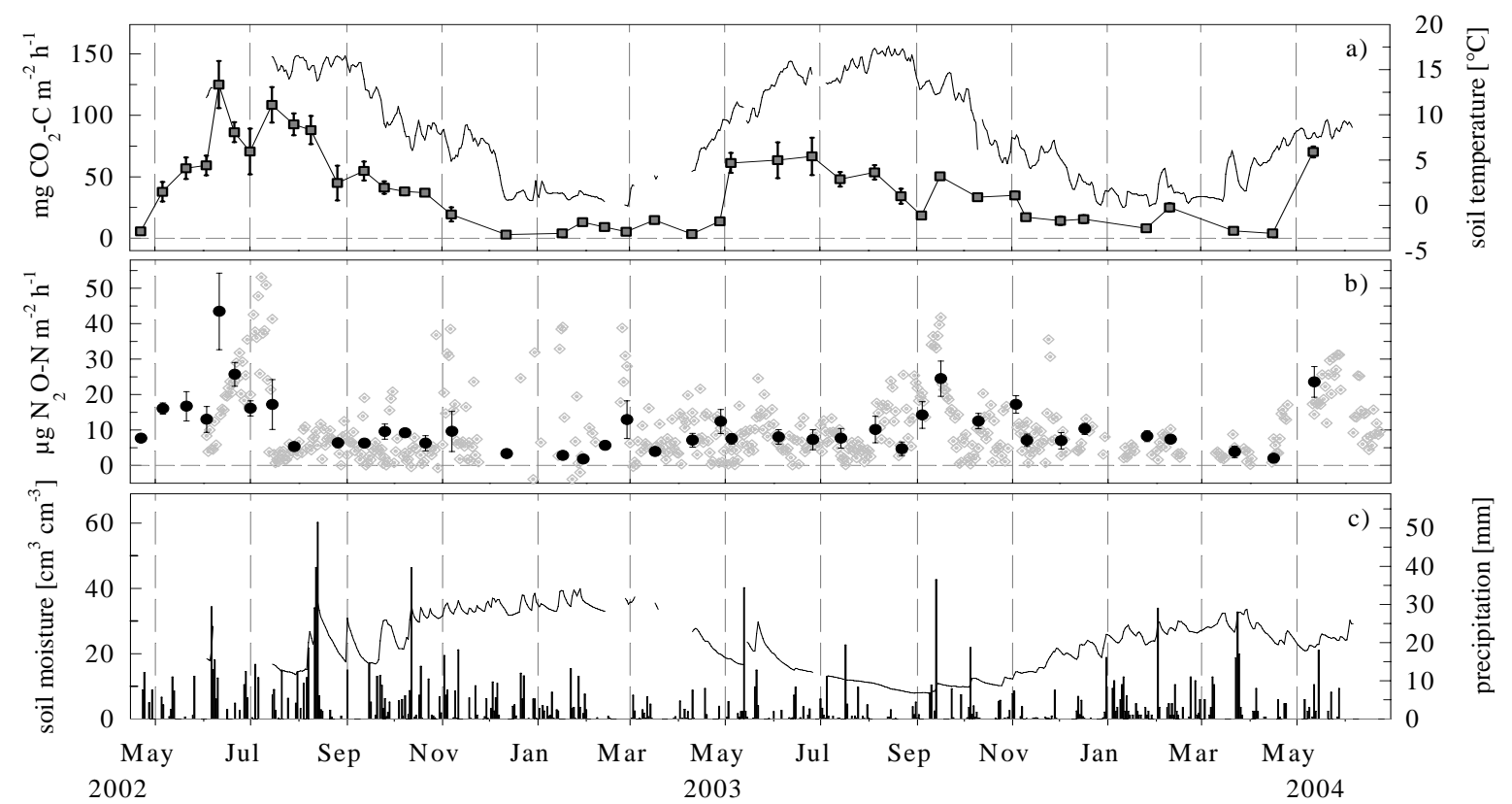

Fig. 5. (a) Mean $\mathrm{CO}_{2}$ emissions (squares \pm S.E) measured with the manual chambers and soil temperature [5 cm] (black line), (b) mean $\mathrm{N}_{2} \mathrm{O}$ emissions from manual (circles \pm S.E) and automatic (diamonds) chambers and (c) daily precipitation (at Mariabrunn) and soil moisture $[15 \mathrm{~cm}]$ at the site Schottenwald from April 2002 to June 2004.

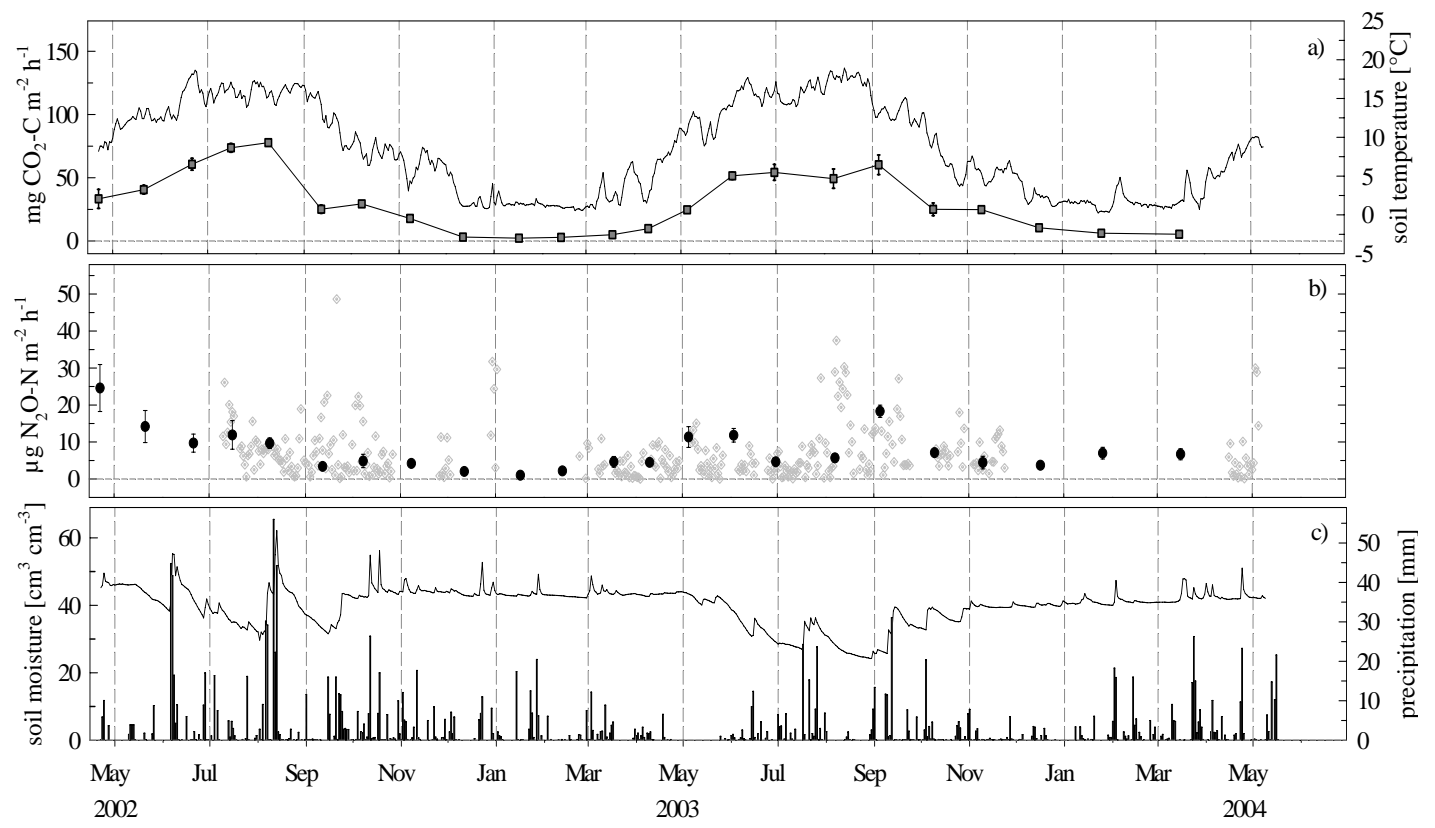

Fig. 6. (a) Mean $\mathrm{CO}_{2}$ emissions (squares \pm S.E) measured with the manual chambers and soil temperature [5 $\left.\mathrm{cm}\right]\left(\right.$ black line), (b) mean $\mathrm{N}_{2} \mathrm{O}$ emissions from manual (circles \pm S.E) and automatic (diamonds) chambers and (c) daily precipitation (at Alland) and soil moisture [15 cm] at the site Klausenleopoldsdorf from May 2002 to May 2004.

$54.2 \mu \mathrm{g} \mathrm{NO}_{2} \mathrm{~m}^{-3}$ in $\mathrm{SW}$ and $\mathrm{KL}$, respectively. Under the assumption that the above mentioned deposition velocities are correct we estimated a depostion of $\mathrm{NH}_{3}$ and $\mathrm{NO}_{2}$ of 2.38 and $0.85 \mathrm{~kg} \mathrm{~N} \mathrm{ha}^{-1} \mathrm{y}^{-1}$ in SW and KL, respectively, thus, displaying highly significant differences between the sites $(p<0.001)$. A total of $20.2 \mathrm{~kg}$ and $12.6 \mathrm{~kg} \mathrm{~N} \mathrm{ha}^{-1} \mathrm{y}^{-1}$ were deposited via wet deposition in SW and KL, respectively (year 1) and it has to be emphasized that $\mathrm{N}$-deposition is dominated by wet deposition at our sites. 


\subsection{Gas fluxes}

\subsection{1 $\mathrm{CO}_{2}$ emissions}

$\mathrm{CO}_{2}$ fluxes are shown in Figs. 5a and 6a. The annual mean of $\mathrm{CO}_{2}$ emissions varied between 33.0 and $43.4 \mathrm{mg} \mathrm{CO}$ C $^{-}$ $\mathrm{C} \mathrm{m}^{-2} \mathrm{~h}^{-1}$ at SW and between 29.2 and $31.6 \mathrm{mg} \mathrm{CO}_{2}-\mathrm{C}$ $\mathrm{m}^{-2} \mathrm{~h}^{-1}$ at KL, respectively (Table 3 ). Significant differences $(p<0.05)$ between the sites were observed mainly during spring and autumn, whereas in summer and winter soil $\mathrm{CO}_{2}$ fluxes did not differ remarkably between the sites. The fluxes showed clear seasonal variations which were strongly related to the air temperature. Maximum mean $\mathrm{CO}_{2}$ fluxes were measured in summer 2002 (Figs. 5b, 6b). Lower emission rates $\left(<70 \mathrm{mg} \mathrm{CO}_{2}-\mathrm{C} \mathrm{m}^{-2} \mathrm{~h}^{-1}\right)$ were observed during the dry summer 2003. At SW a second emission peak could be observed in September, which is probably due to the decomposition of fresh litterfall. At both sites lowest $\mathrm{CO}_{2}$ emission rates were measured in December. In SW $2.9 \mathrm{tC} \mathrm{ha}^{-1} \mathrm{y}^{-1}$ were emitted in the two years whereas in $\mathrm{KL}$ total gaseous C-emissions from soil averaged $2.4 \mathrm{tC} \mathrm{ha}^{-1} \mathrm{y}^{-1}$ (Table 4). A correlation analysis showed that $76 \%$ and $89 \%$ of variances in $\mathrm{CO}_{2}$ emissions at $\mathrm{SW}$ and $\mathrm{KL}$ could be explained by soil temperature $(p<0.001)$. Furthermore, $\mathrm{CO}_{2}$ emissions were negatively correlated with soil moisture in the upper 15 and $30 \mathrm{~cm}$ soil depth (SW: $r^{2}=-0.55$ and KL: $\left.r^{2}=-0.40\right)$.

\subsection{2 $\mathrm{N}_{2} \mathrm{O}$ emissions}

At both sites $\mathrm{N}_{2} \mathrm{O}$ emissions showed a comparable seasonal trend (Figs. $5 \mathrm{~b}$ and $6 \mathrm{~b}$ ) with highest rates in summer and in late autumn.

At SW mean annual $\mathrm{N}_{2} \mathrm{O}$ fluxes amounted to $10.4 \pm 0.6 \mu \mathrm{g}$ $\mathrm{N}_{2} \mathrm{O}-\mathrm{N} \mathrm{m}^{-2} \mathrm{~h}^{-1}$ in the first year of investigation. Maximum emissions occurred in July $2002\left(75.4 \mu \mathrm{g} \mathrm{N}_{2} \mathrm{O}-\mathrm{N} \mathrm{m}^{-2} \mathrm{~h}^{-1}\right)$ and minimum emission rates in winter $2002\left(-6.3 \mu \mathrm{g} \mathrm{N}_{2} \mathrm{O}-\right.$ $\mathrm{N} \mathrm{m}^{-2} \mathrm{~h}^{-1}$ ). Nitrous oxide fluxes of up to $39 \mu \mathrm{g} \mathrm{N} 2 \mathrm{O}-\mathrm{N}$ $\mathrm{m}^{-2} \mathrm{~h}^{-1}$ were observed during winter 2002 and reached almost the same magnitude as the peaks in spring and autumn. These high winter fluxes were observed during a period of warm weather and in connection with the thawing of the soil.

Nitrous oxide fluxes measured in KL were generally lower than those measured in SW (Table 5) except for measurements in April 2002 (39.2 $\left.\mu \mathrm{g} \mathrm{N}_{2} \mathrm{O}-\mathrm{N} \mathrm{m}^{-2} \mathrm{~h}^{-1}\right)$, i.e. at the beginning of the measurements. This might be due to thinning of the stand in the previous winter. The annual mean $\mathrm{N}_{2} \mathrm{O}$ flux was $6.8 \pm 0.5 \mu \mathrm{g} \mathrm{N}_{2} \mathrm{O}-\mathrm{N} \mathrm{m}^{-2} \mathrm{~h}^{-1}$ in the first year with a minimum of $-1.0 \mu \mathrm{g} \mathrm{N}_{2} \mathrm{O}-\mathrm{N} \mathrm{m}^{-2} \mathrm{~h}^{-1}$ in December and a maximum of $82.8 \mu \mathrm{g} \mathrm{N}_{2} \mathrm{O}-\mathrm{N} \mathrm{m}^{-2} \mathrm{~h}^{-1}$ in September. The mean annual $\mathrm{N}_{2} \mathrm{O}$ emissions were higher in the second year (7.6 $\pm 0.5 \mu \mathrm{g} \mathrm{N}_{2} \mathrm{O}-\mathrm{N} \mathrm{m}^{-2} \mathrm{~h}^{-1}$ ) (Table 3).

The variation coefficient between the manual chambers ranged from $20 \%$ to $180 \%$ with highest variations in winter 2002 and in summer 2003.

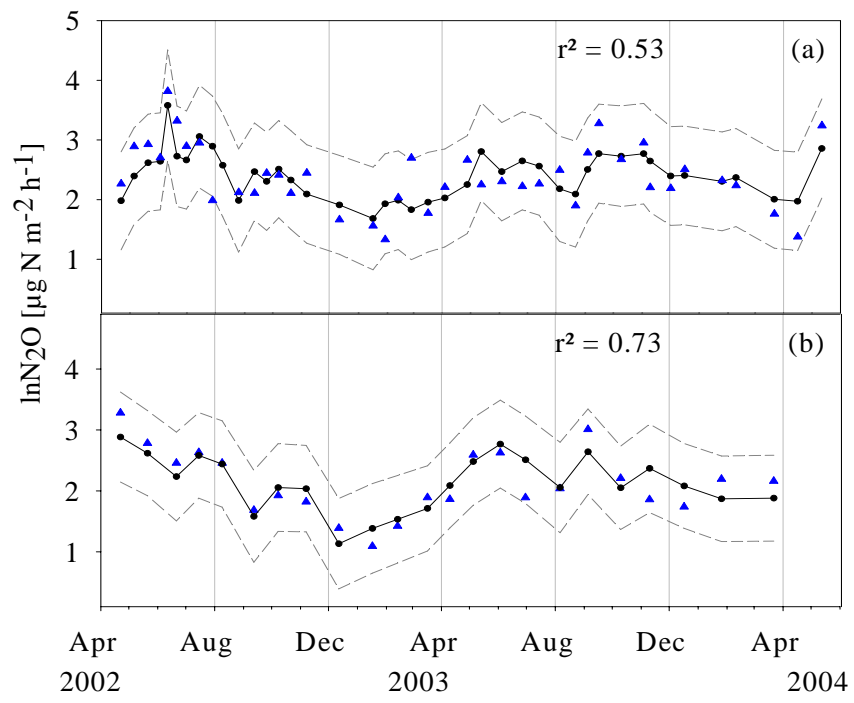

Fig. 7. Measured (triangles), predicted (line with circles) and confidence limits (dashed lines) for log-transformed $\mathrm{N}_{2} \mathrm{O}$ emissions in Schottenwald (a) (Model 1) and Klausenleopoldsdorf (b) (Model 2) over the investigation years. Independent variables are soil moisture, soil temperature and $\mathrm{CO}_{2}$ emission for both sites. Autoregressive parameters are shown in Table 6.

Log-transformed $\mathrm{N}_{2} \mathrm{O}$ emission rates measured by the manual chambers were positively correlated $\left(\mathrm{SW}: r^{2}=0.54\right.$, $\left.\mathrm{KL}: r^{2}=0.56, p<0.001\right)$ with $\mathrm{CO}_{2}$ emission rates and soil temperature $\left(r^{2}=0.29, r^{2}=0.40, p<0.001\right)$. A significant positive dependency was found between soil $\mathrm{N}_{2} \mathrm{O}$ emissions at $\mathrm{SW}$ and $\mathrm{NO}_{3}^{-}-\mathrm{N}$ concentrations in the organic layer $\left(r^{2}=0.43, p<0.01\right)$. There was no significant correlation between $\mathrm{N}_{2} \mathrm{O}$ fluxes and soil extractable $\mathrm{N}\left(\mathrm{NH}_{4}^{+}-\mathrm{N}\right.$ and $\mathrm{NO}_{3}^{-}$$\mathrm{N})$ in $\mathrm{KL}$.

Soil and meteorological parameters correlated with daily fluxes measured by AGPS as follows: Significant correlations (Pearson correlation coefficients) were detected between daily log-transformed $\mathrm{N}_{2} \mathrm{O}$ and $\mathrm{NO}$ fluxes $\left(r^{2}=0.23\right.$; $p<0.001 ; n=289)$ in $\mathrm{SW}$, while at $\mathrm{KL}$ a significant positive relationship with soil temperature $\left(p<0.01 ; r^{2}=0.16 ; n=330\right)$ was demonstrated.

A GARCH $(1,1)$ model was developed to predict mean $\log$-transformed $\mathrm{N}_{2} \mathrm{O}$ emissions from soil, in $\mathrm{SW}$ (Model 1; $r^{2}=0.53$ ) and in KL (Model 2; $r^{2}=0.73$ ) (Figs. 7a, b). Estimated parameters are shown in Table 6. Due to the fact, that $\mathrm{CO}_{2}$ emission rates are significantly correlated with $\mathrm{N}_{2} \mathrm{O}$ emissions, and soil moisture as well as soil temperature have a strong effect on $\mathrm{N}_{2} \mathrm{O}$ emissions these variables were used within the GARCH model. Furthermore these variables were measured regularly and simultaneously with $\mathrm{N}_{2} \mathrm{O}$ emissions from the manual chambers. For model 1 soil temperature was squared for removing negative values. Model 1 revealed a time-lag of 14 , which means that actual $\mathrm{N}_{2} \mathrm{O}$ emissions reflect changes in soil moisture, soil temperature and $\mathrm{CO}_{2}$ 
Table 3. Mean annual $\mathrm{CO}_{2}-\mathrm{C}\left[\mathrm{mg} \mathrm{C} \mathrm{m}^{-2} \mathrm{~h}^{-1}\right], \mathrm{N}_{2} \mathrm{O}-\mathrm{N}$ and NO-N $\left[\mu \mathrm{g} \mathrm{N} \mathrm{m}^{-2} \mathrm{~h}^{-1}\right]$ emissions \pm S.E at Schottenwald and Klausenleopoldsdorf in the two investigation years (year 1: May 2002-April 2003 and year 2: May 2003-April 2004). Minimum and maximum values are in parenthesis.

\begin{tabular}{cccc|ccc}
\hline \multicolumn{3}{c}{$\mathrm{SW}$} & & \multicolumn{3}{l}{$\mathrm{KL}$} \\
\hline & $\begin{array}{c}\mathrm{CO}_{2} \\
{\left[\mathrm{mg} \mathrm{C} \mathrm{m}^{-2} \mathrm{~h}^{-1}\right]}\end{array}$ & $\begin{array}{c}\mathrm{N}_{2} \mathrm{O} \\
{\left[\mu \mathrm{g} \mathrm{N} \mathrm{m}^{-2} \mathrm{~h}^{-1}\right]}\end{array}$ & $\begin{array}{c}\mathrm{CO}_{2} \\
{\left[\mathrm{mg} \mathrm{C} \mathrm{m}^{-2} \mathrm{~h}^{-1}\right]}\end{array}$ & $\begin{array}{c}\mathrm{N}_{2} \mathrm{O} \\
{\left[\mu \mathrm{g} \mathrm{N} \mathrm{m}^{-2} \mathrm{~h}^{-1}\right]}\end{array}$ \\
\hline year 1 & $43.41 \pm 4.1$ & $10.42 \pm 0.6$ & $3.57 \pm 0.1$ & $31.57 \pm 4.0$ & $6.82 \pm 0.5$ & \\
& $(0.7-177.5)$ & $(-6.3-75.4)$ & $(1.2-5.7)$ & $(0.9-82.8)$ & $(-1.0-48.6)$ & \\
year 2 & $33.00 \pm 2.9$ & $10.15 \pm 0.4$ & $7.36 \pm 0.6$ & $29.23 \pm 3.2$ & $7.63 \pm 0.5$ & $0.67^{1)} \pm 0.1$ \\
& $(0.2-103.4)$ & $(0-41.8)$ & $(0.2-44.9)$ & $(2.9-77.6)$ & $(0.03-37.4)$ & $(0-2.2)$ \\
\hline
\end{tabular}

1) Total NO-N emission between August and October 2003.

Table 4. Total measured versus total predicted (bold type) $\mathrm{CO}_{2}-\mathrm{C}, \mathrm{N}_{2} \mathrm{O}-\mathrm{N}$ (manual chambers) and NO-N emissions ( $\pm \mathrm{S}$. E) at Schottenwald and Klausenleopoldsdorf in the two investigation years (year 1: May 2002-April 2003 and year 2: May 2003-April 2004). Predicted values are based on Models 1 to 4 .

\begin{tabular}{|c|c|c|c|c|c|c|c|c|c|c|c|c|}
\hline & \multicolumn{6}{|c|}{ SW } & \multicolumn{6}{|c|}{ KL } \\
\hline & \multicolumn{2}{|c|}{$\begin{array}{c}\mathrm{CO}_{2} \\
{\left[\mathrm{~kg} \mathrm{Cha}^{-1} \mathrm{y}^{-1}\right]}\end{array}$} & \multicolumn{3}{|c|}{$\begin{array}{l}\mathrm{N}_{2} \mathrm{O} \\
\quad\left[\mathrm{kg} \mathrm{Nha}^{-1} \mathrm{y}^{-1}\right.\end{array}$} & $\mathrm{NO}$ & \multicolumn{2}{|c|}{$\begin{array}{c}\mathrm{CO}_{2} \\
{\left[\mathrm{kgCha}^{-1} \mathrm{y}^{-1}\right]}\end{array}$} & \multicolumn{3}{|c|}{${ }^{\mathrm{N}_{2} \mathrm{O}}\left[\mathrm{kg} \mathrm{Nha}^{-1} \mathrm{y}^{-1}\right.$} & NO \\
\hline \multirow[t]{2}{*}{ year 1} & 2916 & \pm 491 & 0.79 & \pm 0.004 & 0.24 & \pm 0.004 & 2413 & \pm 230 & 0.64 & 0.014 & & \\
\hline & & & 0.75 & $\pm \mathbf{0 . 0 0 3}$ & 0.18 & $\pm \mathbf{0 . 0 0 5}$ & & & 0.54 & $\pm \mathbf{0 . 0 3 1}$ & 0.026 & $\pm \mathbf{0 . 0 0 2}$ \\
\hline \multirow[t]{2}{*}{ year 2} & 2875 & \pm 430 & 0.79 & \pm 0.006 & 0.49 & \pm 0.038 & 2315 & \pm 281 & 0.65 & \pm 0.010 & $0.021^{1)}$ & \pm 0.001 \\
\hline & & & 0.82 & $\pm \mathbf{0 . 0 0 5}$ & 0.39 & $\pm \mathbf{0 . 0 2 2}$ & & & 0.67 & $\pm \mathbf{0 . 0 2 1}$ & 0.018 & $\pm \mathbf{0 . 0 0 1}$ \\
\hline
\end{tabular}

1) Total NO-N emission between August and October 2003.

emission over a period of 14 days. For model 2 (KL) mean $\mathrm{CO}_{2}$ emissions $\left(x_{3}\right)$ were $\log$-transformed. As in KL measurements were carried out once a month we could not detect a similar lag at this site as time between the samplings was too large. By applying the GARCH $(1,1)$ model and hence the calculation of an autoregressive error term, significant effects of variables could be detected that had not been visible before (Table 6).

\subsubsection{NO emissions}

In $\mathrm{SW}$ the NO fluxes from soil were measured from June 2002 until May 2004 (Fig. 8a). During winter no flux measurements were carried out. Mean NO emission rates

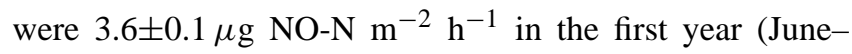
November $2002 ; n=114$ ) with no significant differences between monthly means. In the second year (May 2003January 2004; $n=195$ ) significantly higher emission rates were measured with a mean of $7.4 \pm 0.6 \mu \mathrm{g} \mathrm{NO}-\mathrm{N} \mathrm{m}^{-2} \mathrm{~h}^{-1}$ (Table 3). In this year the variation of NO fluxes between the chambers was higher compared to the fluxes measured in the first year.

Highest NO emissions were measured in September after a rainfall event (35 $\mathrm{mm}$ ), which occurred after an extended dry period at low soil moisture contents $(7-17 \%)$ and at soil temperatures between 10 and $15^{\circ} \mathrm{C}$. $\left(\mathrm{NO}_{\mathrm{x}}-\mathrm{NO}\right)$ was deposited (year 2) with a mean of $-2.7 \pm 0.09 \mu \mathrm{g} \mathrm{N} \mathrm{m}^{-2} \mathrm{~h}^{-1}$. Only in July the soil seemed to act as a weak net source of $\left(\mathrm{NO}_{\mathrm{x}}{ }^{-}\right.$ NO).

To quantify soil $\mathrm{NO}_{\mathrm{x}}$ fluxes at $\mathrm{KL}$ measuring campaigns were carried out between August and October 2003. The mean NO fluxes measured in this period were $0.7 \pm 0.1 \mu \mathrm{g}$ NO-N m${ }^{-2} \mathrm{~h}^{-1}$ in $\mathrm{KL}$, whereas for the same period of time, significantly $(p<0.001)$ higher NO fluxes (Fig. 8b) with a mean of $10.4 \pm 1.3 \mu \mathrm{g} \mathrm{N} \mathrm{m}^{-2} \mathrm{~h}^{-1}(-0.8$ to $44.9 \mu \mathrm{g} \mathrm{N} \mathrm{m}^{-2} \mathrm{~h}^{-1}$ ) were detected at $\mathrm{SW}$. At KL a weaker deposition of $\left(\mathrm{NO}_{\mathrm{x}}-\mathrm{NO}\right)$ was observed with a mean of $-0.6 \pm 0.06 \mu \mathrm{g} \mathrm{N} \mathrm{m}^{-2} \mathrm{~h}^{-1}$.

Daily variations in NO emission could partly be explained by changes in soil temperature at a depth of 5$30 \mathrm{~cm}\left(r^{2}=0.23, p<0.001\right)$, and by air temperature $\left(r^{2}=0.17\right.$, $p<0.01$ ), respectively. $\mathrm{NO}$ and $\mathrm{N}_{2} \mathrm{O}$ emissions were positively correlated $\left(r^{2}=0.23, p<0.001\right)$ in SW. A simple regression model could not be developed to identify relationships between NO emissions and other parameters because residuals were correlated over time. An autoregression model (Model 3) was developed, where soil moisture at $15 \mathrm{~cm}$ soil 
Table 5. Monthly mean $\mathrm{N}_{2} \mathrm{O}$ and $\mathrm{NO}$ emissions in $\mu \mathrm{g} \mathrm{N} \mathrm{m}^{-2} \mathrm{~h}^{-1}$ derived from (a) manual chambers (in Schottenwald-biweekly, in Klausenleopoldsdorf-monthly) and (b) AGPS system (1/day) and the continuous dynamic system (c).

\begin{tabular}{|c|c|c|c|c|c|c|c|c|c|}
\hline & \multicolumn{6}{|c|}{ SW } & \multicolumn{3}{|c|}{ KL } \\
\hline & \multicolumn{4}{|c|}{$\mathrm{N}_{2} \mathrm{O}$} & \multirow{2}{*}{\multicolumn{2}{|c|}{$\frac{\mathrm{NO}}{\text { (c) }}$}} & \multicolumn{2}{|r|}{$\mathrm{N}_{2} \mathrm{O}$} & \multirow{2}{*}{$\frac{\mathrm{NO}}{\text { (c) }}$} \\
\hline & (a) & & (b) & & & & (a) & (b) & \\
\hline Apr-02 & 7.65 & & & & & & 24.59 & $*$ & \\
\hline May-02 & 16.37 & & & & & & 14.17 & & \\
\hline Jun-02 & 27.53 & $*$ & 18.40 & & 3.13 & & 9.69 & & \\
\hline Jul-02 & 12.86 & & 17.63 & & 3.69 & & 11.90 & 10.96 & \\
\hline Aug-02 & 6.35 & & 6.87 & & 3.51 & & 9.68 & 6.41 & \\
\hline Sep-02 & 7.89 & $*$ & 6.04 & & 3.56 & & 3.39 & 8.07 & \\
\hline Oct-02 & 7.71 & & 4.42 & & 3.66 & & 4.85 & 6.27 & \\
\hline Nov-02 & 9.57 & & 11.91 & $*$ & & & 4.18 & $3.43^{3)}$ & \\
\hline Dec-02 & 3.29 & & $17.52^{1)}$ & & & & 2.01 & $14.22^{3)}$ & \\
\hline Jan-03 & 2.23 & & $10.74^{2)}$ & & & & 0.98 & $16.33^{5)}$ & \\
\hline Feb-03 & 9.27 & & $20.66^{3)}$ & & & & 2.15 & $3.15^{5)}$ & \\
\hline Mar-03 & 3.90 & & 5.37 & & & & 4.63 & 3.54 & \\
\hline Apr-03 & 9.45 & & 8.83 & $* *$ & & & 4.45 & 3.96 & \\
\hline May-03 & 7.50 & & 8.81 & $*$ & 5.49 & & 11.35 & 5.57 & \\
\hline Jun-03 & 7.64 & & 5.73 & $*$ & 4.88 & $* * *$ & 11.82 & 3.33 & \\
\hline Jul-03 & 7.65 & & 5.78 & $*$ & 3.80 & $* * *$ & 4.62 & 4.63 & 0.64 \\
\hline Aug-03 & 7.41 & & 13.09 & & 3.42 & & 5.68 & 12.47 & \\
\hline Sep-03 & 19.35 & & 20.35 & $* *$ & 21.22 & $* * *$ & 18.30 & 9.67 & 1.04 \\
\hline Oct-03 & 12.51 & & 7.59 & & 11.31 & $* * *$ & 7.10 & 7.64 & 0.29 \\
\hline Nov-03 & 12.13 & $*$ & 9.81 & & 6.47 & & 4.42 & 6.42 & \\
\hline Dec-03 & 8.43 & & $6.73^{2)}$ & & 2.08 & & 3.69 & & \\
\hline Jan-04 & 8.21 & & $3.80^{4)}$ & & 2.64 & & 6.97 & & \\
\hline Feb-04 & 7.37 & & $5.38^{2)}$ & & & & & & \\
\hline Mar-04 & 3.82 & & 3.68 & & & & 6.68 & & \\
\hline Apr-04 & 1.97 & & 7.72 & $*$ & & & & 3.50 & \\
\hline May-04 & 23.56 & & 22.20 & & 3.41 & & & 16.01 & \\
\hline Jun-04 & & & 12.14 & & & & & & \\
\hline
\end{tabular}

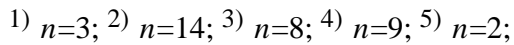

Asterisks marks significant higher values between the sites $(* p<0.05, * * p<0.01$, *** $p<0.001)$.

Table 6. Parameter estimation for the autoregression models 1 to 5 (Eq. 1) to predict $\ln \mathrm{N}_{2} \mathrm{O}$ and NO emissions from Schottenwald and Klausenleopoldsdorf.

\begin{tabular}{|c|c|c|c|c|c|c|c|c|c|c|}
\hline site & \multicolumn{2}{|l|}{ SW } & \multicolumn{2}{|l|}{ KL } & \multicolumn{2}{|c|}{ SW } & \multicolumn{2}{|c|}{$\mathrm{KL}$} & \multicolumn{2}{|c|}{$\mathrm{SW}+\mathrm{KL}$} \\
\hline Model & \multicolumn{2}{|l|}{1} & \multicolumn{2}{|l|}{2} & \multicolumn{2}{|l|}{3} & \multicolumn{2}{|l|}{4} & \multicolumn{2}{|l|}{5} \\
\hline dependent variable: $y_{t}$ & \multicolumn{2}{|c|}{$\ln _{2} \mathrm{O}$} & \multicolumn{2}{|c|}{$\ln \mathrm{N}_{2} \mathrm{O}$} & \multicolumn{2}{|c|}{$\mathrm{NO}$} & \multicolumn{2}{|l|}{$\mathrm{NO}$} & \multicolumn{2}{|l|}{ NO } \\
\hline $\begin{array}{l}\text { Intercept: } \beta_{0} \\
\text { regression coefficients of }\end{array}$ & $\begin{array}{l}2.9356 \\
\text { independer }\end{array}$ & $\begin{array}{l}* * * \\
\text { varia }\end{array}$ & $\begin{array}{l}6.0238 \\
\text { les: }\end{array}$ & $* * *$ & 3.6122 & $* * *$ & 5.0715 & $*$ & 5.2686 & $* * *$ \\
\hline (soil moisture) $\beta_{1}$ & -0.0325 & $* *$ & -0.1028 & $* * *$ & -0.0757 & $* *$ & -0.1015 & $* *$ & -0.0853 & $* * *$ \\
\hline (soil temperature) $\beta_{2}$ & -0.0026 & $* *$ & 0.0561 & $*$ & 0.2086 & $* * *$ & 0.1978 & $* * *$ & 0.0569 & $* *$ \\
\hline$\left(\mathrm{CO}_{2}\right.$ emission $) \beta_{3}$ & 0.0139 & $* * *$ & 0.7427 & $* * *$ & & & & & & \\
\hline total $R^{2}$ : & 0.53 & & 0.73 & & 0.95 & & 0.73 & & 0.85 & \\
\hline$n$ & 41 & & 23 & & 119 & & 53 & & 172 & \\
\hline
\end{tabular}

Sample period is from April 2002-May 2004 and for model 4 from August-October 2003. Regression coefficients are statistically significant at the $* p<0.05, * * p<0.01, * * * p<0.001$ level. 


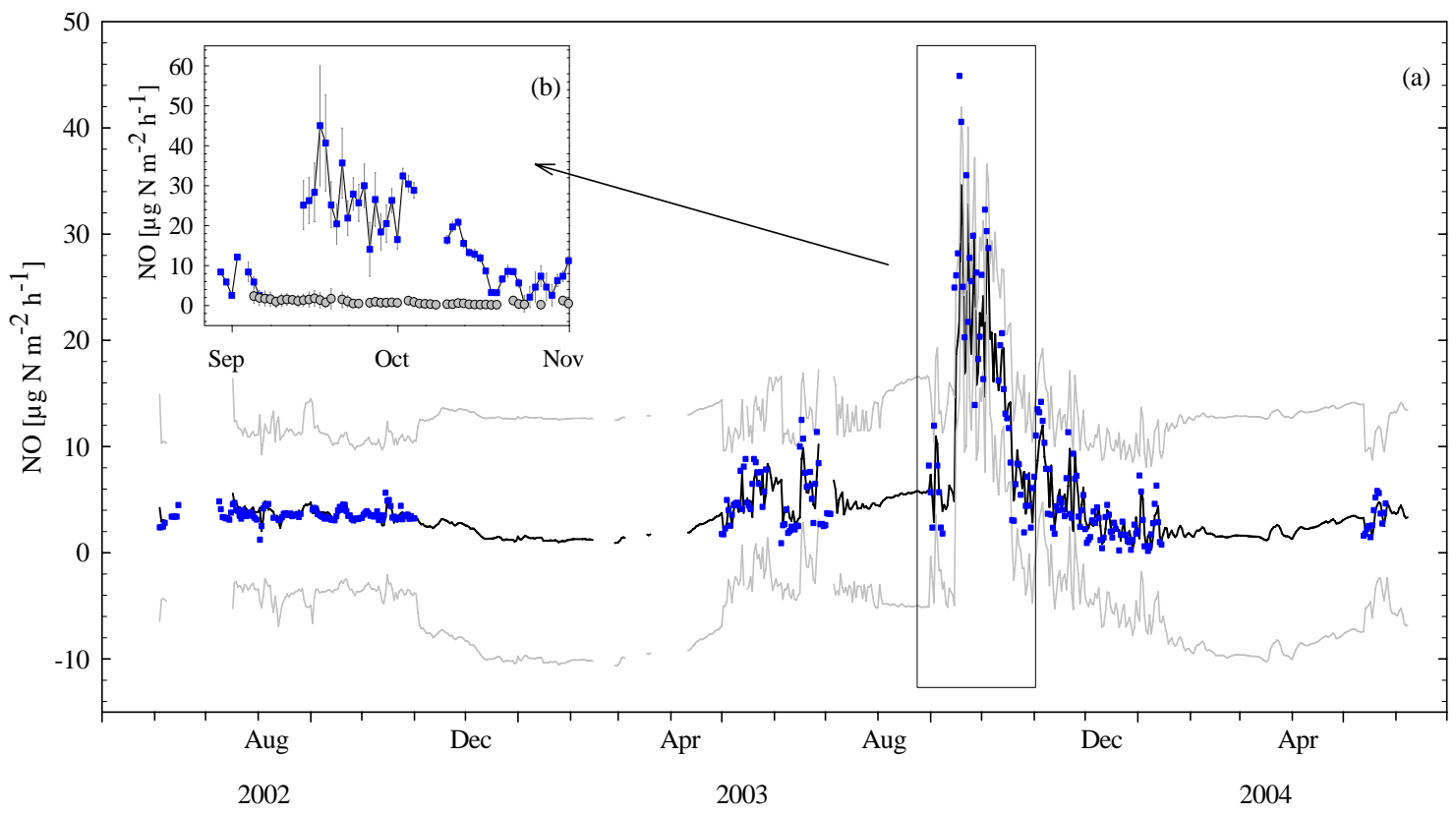

Fig. 8. (a) Measured mean (squares), predicted (black line) and confidence limits (grey line) of NO emission data in Schottenwald between 2002 and 2004. Predicted NO emissions are based on observed soil temperature and soil moisture changes $\left(r^{2}=0.95\right)$. Autoregressive parameters for the model (3) are shown in Table 6 (b) Comparison of emitted NO \pm SE in Schottenwald (squares) and Klausenleopoldsdorf (circles) between August and November 2003.

depth $\left(x_{1 t}\right)$ and soil temperature at $5 \mathrm{~cm}$ soil depth $\left(x_{2 t}\right)$, describes daily mean NO emission with a total $r^{2}$ of 0.95 (Fig. 8a). The model revealed a time-lag of 14, which means that actual $\mathrm{NO}$ emissions reflect changes in soil moisture and soil temperature over a period of 14 days.

At KL, NO emissions showed a significant positive correlation with soil $\left(r^{2}=0.44, p<0.001, n=66\right)$ and air temperature $\left(r^{2}=0.66 p<0.001\right)$. There was no significant correlation between $\mathrm{NO}$ and $\mathrm{N}_{2} \mathrm{O}$ emissions in $\mathrm{KL}\left(r^{2}=0.29, p=0.06\right)$. Nitric oxide emissions in KL could be predicted by soil moisture at a soil depth of $30 \mathrm{~cm}\left(x_{1 t}\right)$ and through soil temperature in $5 \mathrm{~cm}$ soil depth $\left(x_{2 t}\right)$ with a total $r^{2}$ of 0.73 (Model 4). Expressing the prediction of NO emissions of both sites through one model (Model 5) resulted in a 5th order autoregressive model (lag of 5 days) with a total $r^{2}$ of 0.85 (Model $5)$. Soil moisture was the most significant $(p<0.001)$ parameter. Soil temperature was significant at $p<0.01$. Estimated parameters for the models are shown in Table 6 .

\subsubsection{Effects of $\mathrm{N}$-input on gaseous $\mathrm{N}$-emissions}

To identify if $\mathrm{N}$-input affects the gaseous $\mathrm{N}$-emissions on longer time scales monthly mean $\mathrm{N}$ deposition rates were smoothed by using a moving average of 2 or 3 . The correlation coefficients of the mean $\mathrm{N}_{2} \mathrm{O}$ and $\mathrm{NO}$ monthly emission rates measured in $\mathrm{SW}$ and $\mathrm{KL}$ and $\mathrm{N}$-deposition values are outlined in Table 7. The correlation between $\mathrm{N}$ input and $\mathrm{N}$ trace gas emissions were found to be closer for KL, i.e. the less $\mathrm{N}$ saturated site. Correlations between $\mathrm{N}$ input and mean
$\mathrm{N}_{2} \mathrm{O}$ emissions were especially pronounced when calculated from daily measurements. In KL highly significant correlations between $\mathrm{N}_{2} \mathrm{O}$ emissions and deposited $\mathrm{NO}_{3}^{-}$and $\mathrm{NH}_{4}^{+}$ via stemflow were found. In addition, a significant correlation could be demonstrated for $\mathrm{NH}_{4}^{+}$entering the ecosystem via throughfall. In $\mathrm{SW}$ a significant relationship between $\mathrm{N}_{2} \mathrm{O}$ emissions and atmospheric $\mathrm{N}$-deposition could only be demonstrated for dry deposition and $\mathrm{NH}_{4}^{+}$originating from wet (throughfall and stemflow) deposition (Table 7). Furthermore, close correlations were observed between NO emissions, dry $\mathrm{NO}_{2}$ deposition and wet $\mathrm{NH}_{4}^{+}$deposition. No correlation existed between $\mathrm{NO}$ emission and $\mathrm{NO}_{3}^{-}$deposition. Due to the short period of time regarding the measurements of NO at KL (3 months) we could not produce the same statistical analysis for this site.

\section{Discussion}

\section{1 $\mathrm{CO}_{2}$ emissions}

At our sites, between $70-90 \%$ of the temporal variations of soil respiration could be explained by soil temperature. Highest $\mathrm{CO}_{2}$ emissions were detected in spring 2002, when the increase of soil temperature and the mineralization of the litter led to a peak in $\mathrm{CO}_{2}$ emissions. Zechmeister-Boltenstern et al. (2002) found that in $\mathrm{SW}, \mathrm{CO}_{2}$ emission always peaked in late spring due to the fast decomposition of Allium leaves, which cover the ground only from April to June. 
Table 7. Correlation coefficients for significant relationships of monthly mean N-emissions and monthly N-input data at Schottenwald and Klausenleopoldsdorf. Total N-deposition (Total Ndep) is calculated from the first investigation year (May 2002-April 2003) when dry deposition was measured.

\begin{tabular}{|c|c|c|c|c|c|c|c|c|c|c|}
\hline & SW & & KL & & SW & & KL & & \multicolumn{2}{|c|}{ SW } \\
\hline & \multicolumn{4}{|c|}{$\operatorname{lnN}_{2} \mathrm{O}^{1)}$-manual } & \multicolumn{4}{|c|}{$\mathrm{N}_{2} \mathrm{O}^{2)}$-AGPS } & \multicolumn{2}{|c|}{$\mathrm{NO}^{2)}$} \\
\hline $\mathrm{TF} \mathrm{NO}_{3}^{-}-\mathrm{N}$ & & & & & & & & & & \\
\hline $\mathrm{TF} \mathrm{NH}_{4}^{+}-\mathrm{N}$ & & & 0.30 & ** & & & 0.32 & $*$ & & \\
\hline TF sumN & & & 0.23 & * & & & & & & \\
\hline $\mathrm{STEM} \mathrm{NH}_{4}^{+}-\mathrm{N}$ & & & 0.24 & $*$ & & & 0.50 & $* * *$ & & \\
\hline $\mathrm{STEM} \mathrm{NO}_{3}^{-}-\mathrm{N}$ & & & 0.37 & $* *$ & & & 0.76 & $* * *$ & & \\
\hline STEM N & & & 0.36 & $* *$ & & & 0.76 & **** & & \\
\hline WET_NH ${ }_{4}^{+}-\mathrm{N}$ & & & 0.34 & $* * *$ & 0.30 & * & 0.46 & $* * *$ & 0.35 & * \\
\hline WET_NO ${ }_{3}^{-}-\mathrm{N}$ & & & & & & & 0.43 & $* * *$ & & \\
\hline WETsumN & & & 0.28 & $* *$ & & & 0.43 & **** & & \\
\hline $\mathrm{DRY} \mathrm{NO}_{2}-\mathrm{N}$ & -0.50 & $* * *$ & -0.60 & $* * *$ & & & -0.54 & $* *$ & 0.77 & $* * *$ \\
\hline $\mathrm{DRY} \mathrm{NH}_{3}-\mathrm{N}$ & 0.32 & $*$ & 0.58 & $* * *$ & & & & & & \\
\hline DRY_sumN & & & -0.48 & $* * *$ & & & -0.60 & $* * *$ & 0.60 & $* * *$ \\
\hline
\end{tabular}

$\mathrm{TF}=$ throughfall, $\mathrm{STEM}=$ stemflow, WET $=\mathrm{TF}+\mathrm{STEM}, \mathrm{DRY}=\operatorname{dry}$ deposition $\left({ }^{1)}\right.$ Pearson and ${ }^{2)}$ Spearman). Asterisks indicate statistic significance $(* p<0.05$, ** $p<0.01$, *** $p<0.001)$.

Another important variable affecting respiration rates is soil water content. Low $\mathrm{CO}_{2}$ emissions are often observed when soils are either waterlogged or dry (Ball et al., 1999; Lee et al., 2002; Howard and Howard, 1993; Smith et al., 2003). In 2003 a continuous decrease of soil moisture was observed: from $22 \%$ at the end of May to $8 \%$ at early September. This explains why $\mathrm{CO}_{2}$ emissions measured in the summer months of 2003 were significantly lower as compared to emissions measured in summer 2002. In both years and at both sites lowest emission rates were measured at the beginning of the vegetation period as a result of low temperatures and, subsequently, lower activity of heterotrophic microorganisms and root respiration. The overall negative relationship between soil $\mathrm{CO}_{2}$ emissions and soil water content are due to low $\mathrm{CO}_{2}$ emissions in winter during periods of high soil water content. The cumulative $\mathrm{CO}_{2}$ emissions (2.3$2.9 \mathrm{tC} \mathrm{ha}^{-1} \mathrm{y}^{-1}$ ) from the sites (Table 4) are in good agreement with annual $\mathrm{CO}_{2}$ fluxes from temperate, broad-leaved and mixed forest soils as reported by Raich and Schlesinger (1992).

\section{$4.2 \quad \mathrm{~N}_{2} \mathrm{O}$ emissions}

During the two years of measurements $\mathrm{N}_{2} \mathrm{O}$ emissions followed a similar seasonal trend as observed at these sites in earlier years by Meger (1997), Hahn et al. (2000) and Zechmeister-Boltenstern et al. (2002). Highest $\mathrm{N}_{2} \mathrm{O}$ emissions in SW were measured in June 2002 when soils were moist and soil temperatures were high. Schindlbacher et al. (2004) found maximum $\mathrm{N}_{2} \mathrm{O}$ emissions at a soil temperature of $20^{\circ} \mathrm{C}$ and at a water-filled pore space (WFPS) of $85-95 \%$ in laboratory studies with soils from both sites. The reported percentage of WFPS corresponds with a soil moisture content of 50-56\% in SW and 56-63\% in KL. As the soil in SW never reached the moisture optima, significantly higher $\mathrm{N}_{2} \mathrm{O}$ emissions can be expected in the case of high soil moisture content.

In SW the decomposition of decaying Allium leaves led to high $\mathrm{N}$ mineralization rates in early summer (ZechmeisterBoltenstern et al., 2002). The mineralized $\mathrm{N}$ was immediately transformed during nitrification and denitrification resulting in high $\mathrm{N}_{2} \mathrm{O}$ emissions.

The meteorological conditions in the two experimental years were highly different in terms of the occurrence of dry periods and temperature maxima, thus causing pronounced interannual variations. The year 2002 was characterized by a very wet summer. In contrast meteorological conditions observed in summer 2003 showed significantly lower precipitation and higher temperatures: The mean soil moisture was about $10 \%$ lower and mean soil temperature about $0.6^{\circ} \mathrm{C}$ higher. The impact of drought in 2003 was even more pronounced at SW. During summer soil microbial activity, especially the activity of denitrifying bacteria is strongly related to water availability (Schürmann et al., 2002). When soil desiccates, microbial activity is inhibited. High emissions were measured during the first rain after drought. In September 2003, when soil moisture increased from $9 \%$ to $12 \%$ during a precipitation event of $35 \mathrm{~mm}$ rainfall, a sudden increase in $\mathrm{N}_{2} \mathrm{O}$ emissions was observed. Microorganisms in the very dry soil produced high emissions after this rainfall event. Comparable effects of re-wetting of dry temperate forest soils on $\mathrm{N}_{2} \mathrm{O}$ emissions were observed by Brumme et al. (1999). 
In the soil the concentration of $\mathrm{NO}_{3}^{-}$is higher at $\mathrm{SW}$ as compared to the soil at $\mathrm{KL}$ or other soils in the region (Zechmeister-Boltenstern et al., 2002; Hackl et al., 2004); therefore nitrification might play an important role in the production of $\mathrm{N}_{2} \mathrm{O}$ at SW. Both investigation years were characterized by a dry and warm spring. As nitrification is strongly dependent on the $\mathrm{O}_{2}$ concentration in the soil and on soil temperature we hypothesize that, especially in spring, nitrification was the main source of $\mathrm{N}_{2} \mathrm{O}$ production.

Generally, lowest emissions were detected in winter. However, some high winter $\mathrm{N}_{2} \mathrm{O}$ fluxes of up to $39 \mu \mathrm{g} \mathrm{N} \mathrm{N}_{2} \mathrm{O}-$ $\mathrm{N} \mathrm{m}^{-1} \mathrm{~h}^{-1}$ were found after freezing and thawing events. The winter fluxes accounted for $16 \%-32 \%$ of the total annual emissions.

The variation coefficient between the manual chambers ranged from $20 \%$ to $180 \%$ with highest variations in winter 2002 and in summer 2003. At both sites spatial variation can be high and can be explained by different soil moisture conditions between the plots. Topographical differences in the landscape alter hydrological processes and hence $\mathrm{N}_{2} \mathrm{O}$ production/emission as previously reported by Corre et al. (1996).

Total annual $\mathrm{N}_{2} \mathrm{O}$ emissions (mean of AGPS and manual chambers) at $\mathrm{SW}$ were in the range of 0.72 and $0.79 \mathrm{~kg} \mathrm{~N}_{2} \mathrm{O}$ $\mathrm{Nha}^{-1} \mathrm{y}^{-1}$ (Table 4). At the low $\mathrm{N}$-input site $\mathrm{KL}$ annual $\mathrm{N}_{2} \mathrm{O}$ emissions were significantly lower $(0.59$ and $0.62 \mathrm{~kg}$ $\mathrm{N}_{2} \mathrm{O}-\mathrm{N} \mathrm{ha}{ }^{-1} \mathrm{y}^{-1}$ ). The calculated annual $\mathrm{N}_{2} \mathrm{O}$ emission rates at both sites are still to some extent uncertain since e.g. in our measurements diurnal variations are not included and the location of our plots was in interstem areas which might lead to underestimations (Butterbach-Bahl et al., 2002b). Annual $\mathrm{N}_{2} \mathrm{O}$ emissions at $\mathrm{SW}$ and $\mathrm{KL}$ were within the same range as reported for other temperate deciduous forests, which have been shown to vary from 0 to $10 \mathrm{~kg} \mathrm{Nha}^{-1}$ (Brumme and Beese, 1992; Wolf and Brumme, 2003; Brumme et al., 1999; Oura et al., 2001; Papen and Butterbach-Bahl, 1999). In a Danish beech forest (N-input: $\left.25.6 \mathrm{~kg} \mathrm{Nha}^{-1} \mathrm{y}^{-1}\right) \mathrm{N}_{2} \mathrm{O}$ emissions were estimated to be $0.5 \mathrm{~kg} \mathrm{Nha}^{-1} \mathrm{y}^{-1}$ (Beier et al., 2001).

\subsection{1 $\quad \mathrm{N}_{2} \mathrm{O}$ emissions and $\mathrm{N}$-deposition}

One of the questions of our project was, whether nitrogen deposition can have an effect on $\mathrm{N}_{2} \mathrm{O}$ emissions (Brumme et al., 1999) at our sites. Some studies suggest that forests receiving high $\mathrm{N}$-deposition are emitting higher rates of $\mathrm{N}_{2} \mathrm{O}$ than forests exposed to low N-deposition (Castro et al., 1993; Butterbach-Bahl et al., 1997, 2002a). As a consequence of lower precipitation rates wet $\mathrm{N}$-input was lower at both sites in the year 2003 as compared to the year 2002. Nitrous oxide emissions were found to be significantly correlated with precipitation and $\mathrm{N}$-input. In our study $\mathrm{N}_{2} \mathrm{O}$ emissions measured with high time-resolution showed a closer relationship to $\mathrm{N}$-deposition than measurements with high spatial resolution. At the low $\mathrm{N}$-input site $\mathrm{KL}$, higher and stronger corre- lations between $\mathrm{N}_{2} \mathrm{O}$ emissions and $\mathrm{N}$-deposition were observed in comparison to the high $\mathrm{N}$-input site SW (Table 7). These results indicate that low $\mathrm{N}$-deposition sites seem to be more responsive to $\mathrm{N}$-deposition events than forest sites receiving chronically high rates of $\mathrm{N}$ deposition.

\subsection{NO emissions}

At $\mathrm{SW}$ total $\mathrm{NO}$ emissions in the investigation period were 0.2 and $0.5 \mathrm{~kg} \mathrm{~N} \mathrm{ha}^{-1}$ (Table 4). This considerable interannual variation was mainly caused by the extremely contrasting weather conditions during the two years. Soil moisture, followed by soil temperature, were the most important factors affecting the magnitude of soil NO emissions. NO emissions were found to be highest at intermediate soil water contents (van Dijk et al., 2002). Under waterlogged conditions $\mathrm{NO}$ can easily be reduced to $\mathrm{N}_{2} \mathrm{O}$ or $\mathrm{N}_{2}$ before the $\mathrm{N}$ may escape to the atmosphere (Venterea and Rolston, 2000; Davidson et al., 2000). On the other hand, NO emission can also be low, when dry soil conditions constrain microbial activity (Galbally, 1989; Ludwig et al., 2001). In laboratory studies (Schindlbacher et al., 2004) maximum NO emissions occurred at a soil temperature of $20^{\circ} \mathrm{C}$ and a WFPS of 30-45\% at $\mathrm{SW}$ and $65 \%$ at KL. These values correspond to a soil moisture content of $18-26 \%$ and $43 \%$ and are in good agreement with the environmental conditions at periods with highest NO emissions as observed by the field measurements. Rain induced pulses in NO emissions as observed at our sites in September 2003 have also been observed in seasonally dry ecosystems (Davidson, 1992; Otter et al., 1999). At SW a pulse of NO emissions, amounting to almost 50\% of the annual emission, was recorded when soil was moistened after a long dry period, caused by a rainfall event $(<35 \mathrm{~mm})$. The effect of rain on dry soils may lead to a sudden burst of mineralization and nitrification (Schmidt, 1982; Davidson et al., 1991; Williams et al., 1992). This increase of NO emissions can last several days after the water addition (Anderson and Levene, 1987; Slemr and Seiler, 1984).

At both sites $\left(\mathrm{NO}_{\mathrm{x}}-\mathrm{NO}\right)$ was deposited. Mean daily $\left(\mathrm{NO}_{\mathrm{x}}-\mathrm{NO}\right)$ deposition was $-2.7 \mu \mathrm{g} \mathrm{N} \mathrm{m}^{-2} \mathrm{~h}^{-1}$ in $\mathrm{SW}$ and $-0.64 \mu \mathrm{g} \mathrm{N} \mathrm{m}^{-2} \mathrm{~h}^{-1}$ in KL. Only once we observed a weak net emission of $\left(\mathrm{NO}_{\mathrm{x}}-\mathrm{NO}\right)$ from the soil at the $\mathrm{SW}$ site and that was in July 2003. The upward flux of $\left(\mathrm{NO}_{\mathrm{x}}-\mathrm{NO}\right)$ could be explained by the conversion of other nitrogen compounds. HONO for example might be abundant in substantial amounts in forest atmospheres (Kleffmann et al., 2005), but as HONO production (from $\mathrm{NO}_{2}$ ) is most likely working any time also other nitrogen compounds may contribute to an upward flux. It has to be mentioned that $\mathrm{NO}_{\mathrm{x}}$ and $\mathrm{O}_{3}$ was measured in year 2003, but not in year 2002 where we used a filter to remove air impurities. Fluxes might have been overestimated in the first year as the enclosed soil was exposed to low $\mathrm{NO}$ concentrations. $\mathrm{NO}_{2}$ which is deposited to the soil can originate from above the canopy (by advection and subsequent vertical turbulent diffusion into the forest canopy) 
(Jacob and Bakwin, 1992; Rummel et al., 2002; Meixner et al., 2003). On the other hand part of the NO emitted from the soil may be converted to $\mathrm{NO}_{2}$ by reactions with ozone that is vented into the trunkspace from the atmosphere. With the passive diffusion tubes $\mathrm{NO}_{2}$ originating from above the canopy but also converted NO from the soil will be captured and has to be considered when comparing $\mathrm{NO}_{2}$ deposition from the two systems.

\subsubsection{NO emissions and N-deposition}

Mean monthly NO fluxes from the soil in SW ranged between 2.1 and $21.2 \mu \mathrm{g} \mathrm{NO}-\mathrm{N} \mathrm{m}^{-2} \mathrm{~h}^{-1}$ and were, thus significantly $(p<0.001)$ higher than those measured from KL. The $\mathrm{NO}$ emission rates at the site $\mathrm{SW}$ were higher than the values of a deciduous forest ecosystem (oak-hickory: 0.2-4 $\mu \mathrm{g}$ NO$\mathrm{N} \mathrm{m}^{-2} \mathrm{~h}^{-1}$ ) reported by Williams and Fehsenfeld (1991) and within - or slightly lower - than reported NO emissions for the Höglwald beech site in Germany (6.1-47 $\mu \mathrm{g}$ NO-N m ${ }^{-2}$ $\mathrm{h}^{-1}$ ) (Butterbach-Bahl et al., 1997) and for a beech forest at Sorø, Denmark $\left(<1 \mathrm{~kg} \mathrm{NO}_{\mathrm{x}} \mathrm{ha}^{-1} \mathrm{y}^{-1}\right)$ (Beier et al., 2001). At KL $0.02 \mathrm{~kg}$ NO-N ha ${ }^{-1}$ were emitted from soil from August to October 2003. The soil in SW received 70\% more $\mathrm{N}$ from the atmosphere and 16 times more NO was produced $\left(0.32 \mathrm{~kg} \mathrm{Nha}^{-1}\right)$. With these data we assume that there is a relationship between atmospheric $\mathrm{N}$-deposition and NO flux rates at our sites.

\subsection{Time series analysis}

As $\mathrm{N}_{2} \mathrm{O}$ and $\mathrm{NO}$ emission data were autocorrelated over time, time series analysis were conducted to predict $\mathrm{N}_{2} \mathrm{O}$ and $\mathrm{NO}$ emissions from our sites taking time deferred relationships into account. Through the autoregression models the temporal variation of $\mathrm{NO}$ and $\mathrm{N}_{2} \mathrm{O}$ emissions could be explained by soil moisture, soil temperature as well as $\mathrm{CO}_{2}$ emission as an indicator of general microbial activity. The results of GARCH modelling for $\mathrm{N}_{2} \mathrm{O}$ emissions of the individual sites depicted better predicted values (SW: $r^{2}=0.53$ and KL: $r^{2}=0.73$ ) compared to a simple regression model (SW: $r^{2}=0.28$ and KL: $r^{2}=0.46$ ).

Temporal variations in NO emissions could hardly be explained by a simple regression model using soil moisture and soil temperature as drivers (SW: 18\% KL: 39\%). However, when taking previously measured (daily mean) soil moisture and soil temperature into account up to $95 \%$ and $73 \%$ of the variations of NO emission could be explained in SW and KL, respectively. Simulation results were at their best for the year 2002, when variations between the chambers were small due to continuously high soil moisture. As a result of soil desiccation in summer 2003 variation was higher and the fit between simulated and measured values was lower.

The GARCH models revealed a 14-days deferred effect of soil moisture and soil temperature on $\mathrm{N}_{2} \mathrm{O}(\mathrm{SW})$ as well as NO (SW and KL) emissions. We could demonstrate with this statistical procedure that at our sites emissions increased especially when soil moisture was lower (14 days before), combined with favourable soil temperature.

Modelled annual NO emissions for SW amounted to 0.18 and $0.39 \mathrm{~kg} \mathrm{NO}-\mathrm{N} \mathrm{ha}^{-1} \mathrm{y}^{-1}$ for the two years of investigation (Table 4). Using values of mean soil moisture and soil temperature measured daily over a period of two investigation years in order to drive the empirical model, we estimated annual NO-emissions at KL to be in the range of 0.02 and

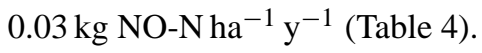

\section{Conclusions}

Our results show that the temporal pattern of $\mathrm{CO}_{2}$ and $\mathrm{N}$-oxides emissions is strongly dependent on temperature. However, short-term fluctuations in $\mathrm{N}$ trace gas emissions can also be modulated by changes in soil moisture or freezing-thawing events. In our study significant interannual variations in the magnitude and seasonality of $\mathrm{N}$ trace gas emissions were demonstrated at both forest sites. Therefore, long-term measurements on a larger scale covering several years - as suggested by Ambus and Christensen (1995) - are needed to finally come up with reliable estimates of forest soil emissions.

Since we found a detectable effect of topographic structures on $\mathrm{N}_{2} \mathrm{O}$ fluxes, we hypothesize that medium scale measurements in the range of several $100 \mathrm{~m}$ would increase the accuracy of nitrous oxide emission estimates from forests. Thus, variability caused by topographic structures could be detected.

We assume that $\mathrm{N}$-input has an impact on $\mathrm{N}$-emissions at our sites. Nitric oxide emissions from the soil were stronger affected by atmospheric $\mathrm{N}$-deposition than $\mathrm{N}_{2} \mathrm{O}$ emission. The temporal relationship between $\mathrm{N}$-inputs and $\mathrm{N}$-emissions was stronger for the $\mathrm{N}$-limited forest ecosystem suggesting that - under increased $\mathrm{N}$-input - such ecosystems can potentially function as strong sources of $\mathrm{N}$ trace gases in the future.

Emission data were autocorrelated over time. Therefore time series analysis was used which revealed patterns that did not become apparent through simple regression models. Nitrogen oxide emissions from soils could be predicted with a higher $r^{2}$. Since there are few studies in soil science which apply more complex models rather than simple regression analysis, we would like to emphasize the potential of such models for data analysis and the prediction of GHGemissions.

Acknowledgements. We would like to thank the forest managers S. Jeitler and J. Wimmer for giving access to their properties. A. Fiege, F. Winter for field work and C. Abo-Elschabaik and M. Kitzler for helping with the sample analysis, S. Wolf for English corrections and K. Gartner for provision of meteorological data. The authors also thank K. Moder, T. Gschwantner for their 
constructive work with statistics and R. Jandl and A. Schindlbacher for comments and F. X. Meixner and three anonymous reviewers for critical discussion and editing. The study is a part of the NOFRETETE project EVK2-CT2001-00106 funded by the European Commission DG Research - Vth Framework Programme.

\section{Edited by: F. X. Meixner}

\section{References}

Aber, J., McDowell, W., Nadelhoffer, K., Magill, A., Berntson, G., Kamakea, M., McNulty, S., Currie, W., Rustad L., and Fernandez I.: Nitrogen saturation in temperate forest ecosystems, BioScience, 48, 921-934, 1998.

Ambus, P. and Christensen, S.: Spatial and seasonal nitrous oxide and methane fluxes in Danish forest-, grassland-, and agroecosystems., J. Environ. Qual., 24, 993-1001, 1995.

Anderson, I. C. and Levene, J. S.: Simultaneous field measurements of nitric oxide and nitrous oxide, J. Geophys. Res., 92, 964-976, 1987.

Ball, B. C., Scott, A., and Parker, J. P.: Field $\mathrm{N}_{2} \mathrm{O}, \mathrm{CO}_{2}$ and $\mathrm{CH}_{4}$ fluxes in relation to tillage, compaction and soil quality in Scotland, Soil Till. Res., 53, 29-39, 1999.

Beier, C., Rasmussen, L., Pilegaard, K., Ambus, P., Mikkelsen, T., Jensen, N. O., Kjøller, A., Priemé, A., and Ladekarl, U. L.: Fluxes of $\mathrm{NO}_{3}^{-}, \mathrm{NH}_{4}^{+}, \mathrm{NO}, \mathrm{NO}_{2}$, and $\mathrm{N}_{2} \mathrm{O}$ in an old Danish beech forest, Water, Air Soil Poll., Focus 1, 187-195, 2001.

Brown, R. H.: Monitoring the ambient environment with diffusive samplers: theory and practical considerations, J. Env. Monit., 2, $1-9,2000$

Brumme, R. and Beese, F.: Effects of liming and nitrogen fertilization on emissions of $\mathrm{CO}_{2}$ and $\mathrm{N}_{2} \mathrm{O}$ from temperate forest, $\mathrm{J}$. Geophys. Res., 97, 12, 851-858, 1992.

Brumme, R., Borken, W., and Finke, S.: Hierachical control on nitrous oxide emission in forest ecosystems, Global Biogeochem. Cycl., 13, 1137-1148, 1999.

Bush, T., Smith, S., Stevenson, K., and Moorcroft, S.: Validation of nitrogen dioxide diffusion tube methodology in the UK, Atmos. Environ., 35, 289-296, 2001.

Butterbach-Bahl, K., Gasche, R., Breuer, L., and Papen, H.: Fluxes of $\mathrm{NO}$ and $\mathrm{N}_{2} \mathrm{O}$ from temperate forest soils: impact of forest type, N-deposition and of liming on $\mathrm{NO}$ and $\mathrm{N}_{2} \mathrm{O}$ emissions, Nutr. Cycl. Agroecosys., 48, 79-90, 1997.

Butterbach-Bahl, K., Breuer, L., Gasche, R., Willibald, G., and Papen, H.: Exchange of trace gases between soils and the atmosphere in Scots pine forest ecosystems of the North Eastern German Lowlands, 1. Fluxes of $\mathrm{N}_{2} \mathrm{O}, \mathrm{NO} / \mathrm{NO}_{2}$ and $\mathrm{CH}_{4}$ at forest sites with different N-deposition, Forest Ecol. Managem., 167, 123-134, 2002a.

Butterbach-Bahl, K., Rothe, A., and Papen, H.: Effect of tree distance on $\mathrm{N}_{2} \mathrm{O}$ and $\mathrm{CH}_{4}$-fluxes from soils in temperate forest ecosystems, Plant Soil, 240, 91-103, 2002b.

Castro, M. S., Steudler, P. A., Melillo, J. M., Aber, J. D., and Millham, S.: Exchange of $\mathrm{N}_{2} \mathrm{O}$ and $\mathrm{CH}_{4}$ between the atmosphere and soils in spruce-fir forests in the north-eastern United States, Biogeochemistry, 18, 119-135, 1993.

Corre, M. D., van Kessel, C., and Pennock, D. J.: Landscape and seasonal patterns of nitrous oxide emissions in a semiarid region, Soil Sci. Soc. Am. J., 60, 1806-1815, 1996.
Dahlgren, R. A. and Singer, M. J.: Nutrient cycling in managed and non-managed oak woodland-grass ecosystems, University of California, Davis, CA, 1994.

Davidson, E. A., Vitousek, P. M., Matson, P. A., Riley, R., GarciaMendez, G., and Maass, J. M.: Soil emissions of nitric oxide in a seasonally dry tropical forest of Mexico, J. Geophys. Res., 96, 15 439-15 445, 1991.

Davidson, E.: Pulses of nitric oxide and nitrous oxide flux following wetting of dry soil: an assessment of probable sources and importance relative to annual fluxes, Ecol. Bull., 42, 149-155, 1992.

Davidson, E. A.: Soil water content and the ratio of nitrous oxide to nitric oxide emitted from soil, in: Biogeochemistry of global change, edited by: Oremland, R. S., Chapman and Hall, New York, 369-386, 1993.

Davidson, E. A. and Kingerlee, W.: A global inventory of nitric oxide emissions from soils, Nutr. Cycl. Agroecosys., 48, 37-50, 1997.

Davidson, E. A., Keller, M., Erickson, H. E., Verchot, L. V., and Veldkamp, E.: Testing a conceptual model of soil emissions of nitrous and nitric oxides, BioScience, 50, 667-680, 2000.

Fitzhugh, R. D., Driscoll, C. T., Groffman, P. M., Tierney, G. L., Fahey, T. J., and Hardy, J. P.: Effects of soil freezing disturbance on soil solution nitrogen, phosphorus and carbon chemistry in a northern hardwood ecosystem, Biogeochemistry, 56, 215-238, 2001.

Galbally, I. E.: Factors controlling $\mathrm{NO}_{\mathrm{x}}$ emissions from soil, in: Exchange of Trace Gases between Terrestrial Ecosystems and the Atmosphere, edited by: Andreae, M. O. and Schimel, D. S., John Wiley, New York, 23-37, 1989.

Galloway, J. N., Schlesinger, W. H., II, H. L., Michaels, A., and Schnorr, J. L.: Nitrogen fixation: anthropogenic enhancementenvironmental response, Global Biogeochem. Cycl., 9, 2, 235252, 1995

Gundersen, P., Emmett, B. A., and Konaas, O. J.: Impact of nitrogen deposition on nitrogen cycling in forests: a synthesis on NITREX data, Forest Ecol. Managem., 101, 37-55, 1998.

Hackl, E., Bachmann, G., and Zechmeister-Boltenstern, S.: Microbial nitrogen turnover in soils under different types of natural forest, Forest Ecol. Managem., 188, 101-112, 2004.

Hahn, M., Gartner, K., and Zechmeister-Boltenstern, S.: Greenhouse gas emissions $\left(\mathrm{N}_{2} \mathrm{O}, \mathrm{CO}_{2}\right.$ and $\left.\mathrm{CH}_{4}\right)$ from beech forests near Vienna with different water and nitrogen regimes, Die Bodenkultur - Austrian Journal of Agricultural Research, 51, 91$101,2000$.

Hall, S. J. and Matson, P. A.: Nitrogen oxide emissions after nitrogen additions in tropical forests, Nature, 400, 152-155, 1999.

Holtermann, C.: A transportable system for the on-linemeasurement of $\mathrm{NO}_{\mathrm{x}}\left(\mathrm{NO}, \mathrm{NO}_{2}\right)$ emission from soils, Die Bodenkultur, 47, 235-244, 1996.

Howard, D. M. and Howard, P. J.: Relationships between $\mathrm{CO}_{2}$ evolution, moisture content and temperature for a range of soil types, Soil Biol. Biochem., 25, 1537-1546, 1993.

IAEA: Manual on measurements of methane and nitrous oxide emissions from agriculture, International Atomic Energy Agency, Vienna, 90, 1992.

Jacob, D. J. and Bakwin, P. S.: Cycling of NO in tropical forest canopies, in: Microbial Production and Consumption of Greenhouse Gases, edited by: Whitman, W. B., American Society of 
Microbiology, Washington, D.C., 237-253, 1992

Kandeler, E.: Ammonium and Nitrate, in: Methods of Soil Biology, edited by: Schinner, F., Öhlinger, T., Kandeler, E., and Margesin, R., Springer, Berlin, 406-410, 1995.

Kleffmann, J. Gaviloaiei, T., Hofzumahaus, A., Holland, F., Koppmann, R., Rupp, L., Schlosser, E., Siese, M., and Wahner, A.: Daytime formation of nitrous acid: A major source of $\mathrm{OH}$ radicals in a forest, Geophys. Res. Lett., 32, 1-4, 2005.

Krupa, S. V. and Legge, A. H.: Passive sampling of ambient, gaseous air pollutants: an assessment from an ecological perspective, Environ. Poll., 107, 31-45, 2000.

Lee, M. S., Nakane, K., Nakatsubo, T., Mo, W. H. and Koizumi, $\mathrm{H}$.: Effects of rainfall events on soil $\mathrm{CO}_{2}$ flux in a cool temperate deciduous broad-leave forest, Ecol. Res., 17, 401-409, 2002.

Lovett, G. M., Weathers, K. C., and Arthur, M. A.: Control of nitrogen loss from forested watersheds by soil carbon: Nitrogen ratio and tree species composition, Ecosystems, 5, 712-718, 2002.

Ludwig, J.: Untersuchungen zum Austausch von $\mathrm{NO}$ und $\mathrm{NO}_{2}$ zwischen Atmosphäre und Biosphäre, $\mathrm{PhD}$ Thesis, University of Bayreuth, 251 pp., 1994.

Ludwig, J., Meixner, F. X., Vogel, B., and Förstner, J.: Processes, influencing factors, and modelling of nitric oxide surface exchange - an overview, Biogeochemistry, 52, 3, 225-257, 2001.

MacDonald, J. A, Dise, N. B., Matzner, E., Armbruster, M., Gundersen, P., Forsius, M.: Nitrogen input together with ecosystem nitrogen enrichment predict nitrate leaching from European forests, Global Change Biol., 8, 1028-1033, 2002.

Mayer, H.: Wälder des Ostalpenraumes, Fischer Verlag, 344, 1974.

Meger, S.: Sticksoffkreislauf und Methanoxidation in Buchenwäldern, University Vienna, Vienna, 106, 1997.

Meixner, F. X., Andreae, M. O., van Dijk, S. M., Gut, U. A., Rummel, U. K., Scheibe, M., and Welling, M.: Biosphere-atmosphere exchange of reactive trace gases in a primary rainforest ecosystem : studies on interlinking scales, Report Series in Aerosol Science, 62A, 269-274, 2003.

NADP: National Atmospheric Deposition Program 2001 Summary. NADP Report, http://nadp.sws.uiuc.edu/lib/data/2001as.pdf, Illinois State Water Survey, Champaign, IL, 2002.

Otter, L., Yang, W., Scholes, M., and Meixner, F. X.: Nitric oxide emissions from a southern African savanna, J. Geophys. Res., 104, 18 471-18 485, 1999.

Oura, N., Shindo, J., Fumoto, F., Toda, H., and Kawashima, H.: Effects of nitrogen deposition on nitrous oxide emissions from the forest floor, Water, Air Soil Poll., 130, 673-678, 2001.

Papen, H. and Butterbach-Bahl, K.: A 3-year continuous record of nitrogen trace gas fluxes from untreated and limed soil of a Nsaturated spruce and beech forest ecosystem in Germany, 1. $\mathrm{N}_{2} \mathrm{O}$ emissions, J. Geophys. Res. 104, 18 487-18 503, 1999.

Pilegaard, K., Hummelshoj, P., and Jensen, N. O.: Nitric oxide emission from a Norway spruce forest floor, J. Geophys. Res., 104, 3433-3445, 1999.

Raich, J. W. and Schlesinger, W. H.: The global carbon dioxide flux in soil respiration and its relationship to vegetation and climate, Tellus, 44B, 81-99, 1992.

Rennenberg, H., Kreutzer, K., Papen, H., and Weber, P.: Consequences of high loads of nitrogen for spruce (Picea abies) and beech (Fagus sylvatica) forests, New Phytol., 139, 1, 71-86, 1998.

Rummel, U., Ammann, C., Gut, A., Meixner, F. X., and An- dreae, M. O.: Eddy covariance measurements of nitric oxide flux within an Amazonian rain forest, J. Geophys. Res., 107, 8050, doi:10.1029/2001JD000520, 2002.

SAS/ETS: User's Guide. Version 8. Cary: Statistical Analysis System Institute, 1993.

Schindlbacher, A., Zechmeister-Boltenstern, S., and ButterbachBahl, K.: Effects of soil moisture and temperature on $\mathrm{NO}, \mathrm{NO}_{2}$ and $\mathrm{N}_{2} \mathrm{O}$ emissions from forest soils, J. Geophys. Res., 109, D17302, 1-12, 2004.

Schmidt, E. L.: Nitrification in soil, in: Nitrogen in agricultural soils, edited by: Stevenson, F .J., Agron. Monogr., 22, ASA, CSSA, and SSSA, Madison, WI, 253-288, 1982.

Schürmann, A., Mohn, J., and Bachofen, R.: $\mathrm{N}_{2} \mathrm{O}$ emissions from snow-covered soils in the Swiss alps, Tellus B, 54, 2, 134-142, 2002.

Skiba, U. M., Sheppard, L. J., MacDonald, J., and Fowler, D.: Some key environmental variables controlling nitrous oxide emissions from agricultural and semi-natural soils in Scotland, Atmos. Environ., 32, 3311-3320, 1998.

Skiba, U., Sheppard, L. J., Pitcairn, C. E. R., VanDijk, S., and Rosall, M. J.: The effect of N-deposition on nitrous oxide and nitric oxide emissions from temperate forest soils, Water, Air Soil Poll., 116, 89-98, 1999.

Slemr, F. and Seiler, W.: Field Measurements of $\mathrm{NO}$ and $\mathrm{NO}_{2}$ Emissions from Fertilized and Unfertilized Soils, J. Atmos. Chem., 2, 1-24, 1984.

Smith, K. A. Ball, T., Conen, F., Dobbie, D. E., Massheder, J., and Rey, A.: Exchange of greenhouse gases between soil and atmosphere: Interactions of soil physical factors and biological processes, Eur. J. Soil Sci., 54, 4, 779-791, 2003.

Stevenson, K., Bush, T., and Mooney, D.: Five years of nitrogen dioxide measurement with diffusion tube samplers at over 1000 sites in the UK, Atmos. Environ., 35, 281-287, 2001.

Sutton, M. A., Tang, Y. S., Miners, B., and Fowler, D.: A new diffusion denuder system for long-term, regional monitoring of atmospheric ammonia and ammonium., Water, Air Soil Poll., Focus 1, Part 5/6, 145-156, 2001.

Tang, Y. S., Cape, J. N., and Sutton, M. A.: Development and types of passive samplers for monitoring atmospheric $\mathrm{NO}_{2}$ and $\mathrm{NH}_{3}$ concentrations, The Scientific World, 1, 513-529, 2001.

Tietema, A.: Mass loss and nitrogen dynamics in decomposing acid forest litter in the Netherlands at increased nitrogen deposition, Biogeochemistry, 20, 45-62, 1993.

Van Breemen, N., Burrough, P. A., Velthorst, E. J., van Dobben, H. F., de Wit, T., Ridder, T. B., and Reijnders H. F. R.: Soil acidification from atmospheric ammonium sulphate in forest canopy throughfall, Nature, 299, 548-550, 1988.

Van Dijk, S. M., Gut, A., Kirkman, G. A., Meixner, F. X., and Andreae, M. O.: Biogenic NO emissions from forest and pasture soils: Relating laboratory to field measurements, J. Geophys. Res., 107, D20, 8058, doi:10.1029/2001JD000358, 2002.

Venterea, R. T. and Rolston, D. E.: Mechanisms and kinetics of nitric and nitrous oxide production during nitrification in agricultural soil, Global Change Biol., 6, 303-316, 2000.

Venterea, R. T., Groffman, P. M, Verchot, L. V., Magill, A. H., Aber, J. D., and Steudler, P. A.: Nitrogen oxide gas emissions from temperate forest soils receiving long-term nitrogen inputs, Global Change Biol., 9, 346-357, 2003.

Williams, E. J. and Fehsenfeld, F. C.: Measurement of soil nitrogen 
oxide emissions at three North American ecosystems, J. Geophys. Res., 96, 1033-1042, 1991.

Williams, E. J., Hutchinson, G. L., and Fehsenfeld, F. C.: $\mathrm{NO}_{\mathrm{x}}$ and $\mathrm{N}_{2} \mathrm{O}$ emissions from soil, Global Biogeochem. Cycl., 6, 351388, 1992 .
Wolf, I. and Brumme, R.: Dinitrogen and nitrous oxide formation in beech forest floor and mineral soils, Soil Sci. Soc. Am. J., 67, 1862-1868, 2003.

Zechmeister-Boltenstern, S., Hahn, M., Meger, S. and Jandl, R.: Nitrous oxide emissions and nitrate leaching in relation to microbial biomass dynamics in a beech forest soil, Soil Biol. Biochem., 34, 823-832, 2002. 